\title{
LOOKING AT THE WORKS OF ALICE TAWHAI: AN ARGUMENT FOR MĀORI LITERARY NATIONALISM
}

\author{
By \\ Charlie (Natasha) Holland
}

A thesis presented to The Victoria University of Wellington in fulfillment of the requirements for the degree of Master of Arts in English

Victoria University of Wellington

October 2009 


\section{Acknowledgments}

I would like to thank my supervisor Dr. Alice Te Punga Somerville for all her support and to Prof. Lydia Wevers for helping me in the final stages of completing my work. To the organisers of the Manurere Postgraduate Travel Grant, Federation of Graduate Women (Wellington Branch), Te Ha and Ngā Pou Kaituhi Māori committees of Toi Māori Aotearoa, and especially my Mum for funding my trip to Albuquerque, New Mexico for the 2009 Native American Literary Symposium - thank you. I would also like to thank my partner Jayde for her continuous support over the years it has taken me to research and produce this thesis. 


\begin{abstract}
Contemporary Māori writer Alice Tawhai has published two collections of short stories, Festival of Miracles (2005) and Luminous (2007). Tawhai's narratives portray Māori people living an array of diverse lifestyles and her collections include stories about isolation, gangs, substance abuse, identity, education, art and spirituality; her work has been reviewed in literary magazines and online as new fiction that reflected a contemporary society in Aotearoa and these literary reviews imply that Tawhai's stories are a reflection of Māori people. For Māori readers, Tawhai's narratives demand a different interpretation of the text, a different way of reading, in order to read these stories of their own merits. To this end, this thesis proposes a practice for reading called 'Māori literary nationalism' which is based on a book called, American Indian Literary Nationalism whose proposed literary practice can be suitably adapted for a Maori literary context. One of the most important components of Maori literary nationalism is the idea of keeping Māori as the central focus, analyzing Māori literature with an insider's view. Māori literary nationalism provides a space for Māori readers to discuss literature, exchange ideas and encourage dialogue amongst each other. More importantly Māori literary nationalism offer Māori readers an opportunity to read Alice Tawhai’s work in a way that foregrounds the uniqueness of her short stories.
\end{abstract}




\section{Contents}

$\begin{array}{ll}\text { Introduction } & 1\end{array}$

The insider's view and 'Pale Flower' 29

$\begin{array}{ll}\text { Reader } & 31\end{array}$

$\begin{array}{ll}\text { Writer } & 47\end{array}$

$\begin{array}{ll}\text { Text } & 51\end{array}$

Literary Nationhood and a Festival of Miracles 60

The Indigenous Nation and Luminous $\quad 79$

$\begin{array}{lr}\text { Conclusion } & 98\end{array}$

American Indian Literary Nationalism 98

Māori Literary Nationalism 101

$\begin{array}{ll}\text { Alice Tawhai } & 105\end{array}$

$\begin{array}{ll}\text { Bibliography } & 106\end{array}$

$\begin{array}{ll}\text { Primary Sources } & 106\end{array}$

$\begin{array}{ll}\text { Secondary Sources } & 111\end{array}$ 


\section{Introduction}

In 2005 I read a collection of short stories by a new Māori writer by the name of Alice Tawhai. Her fiction was like nothing that I had ever read before and I considered what it was about these particular stories that I liked so much. I felt as though I had made a connection with the text at a personal level. Tawhai's stories described incidents, activities and characters that I could relate to as a Māori woman living in Aotearoa. I was so excited about discovering Tawhai's short stories that I often read them out loud to my partner, encouraged my sister to read Tawhai's works and brought copies of the book for my cousins and friends.

On different occasions with friends and family I casually discussed Tawhai's work, often trying to pinpoint locations and time periods that the writer was describing through her narratives. Our conversations were easy and we understood and felt comfortable discussing themes, plots and references from different parts of the book. In 2007, Tawhai released another collection of short fiction and I was just as excited to read her new works and share my thoughts with others who had read Tawhai's fiction. I looked online and in the 'book' sections of magazines to see what sort of reviews Tawhai had been receiving and to see if the literature reviewers were as enthusiastic as I was. However, what I read was not what I had expected. Literary reviewers were making statements that 
Tawhai's stories, "expose the dark underbelly of 21st-century New Zealand life"1, and have characters who live in the "margins of life", "[settings that are] readily recognisable, but it also made me feel a little uncomfortable" ${ }^{3}$ and as one reviewer pointed out in reference to these social underbelly characters, "many are Māori" ${ }^{4}$. In fact, if the characters were not Māori then they are likely to be an ethnic minority, since there are very few Pākehā characters featured throughout her narratives.

Tawhai is a contemporary Māori short fiction writer who explores stories about real issues concerning Māori; Māori characters who are in gangs, consumption of illegal substances, abusive relationships and people who live within a lower social-economic context. These Māori characters are representations of the same people in my extended family, my community, my group of friends, and ultimately my Māori culture. Not once have I ever regarded them as the underbelly of $21^{\text {st }}$ century New Zealand life or as living on the margins, as these literary reviewers have. I began to feel defensive about the narratives and felt I could only discuss Tawhai's stories with other Māori people so that I wouldn't have to justify the behavior and actions of the characters.

In 2006, I attended a literary event by visiting writer, Célestine Hitiura Vaite, who came to New Zealand on an author tour. After reading Vaite's books, Breadfruit and Frangipani, I discovered the values and lifestyles portrayed in these books and the narratives regarding social structures; attitudes towards non-indigenous people; and

\footnotetext{
${ }^{1}$ Philippa Jamieson, 'Private Life' in New Zealand Listener, June 28-July 4 2008, Vol. 214: No 3555

${ }^{2}$ Louise Wareham Leonard, 'Festival of Miracles by Alice Tawhai', Leaf Salon URL: http://www.leafsalon.co.nz/archives/000670festival_of_miracles_by_alice tawhai.html accessed on 4 Jan 2009

${ }^{3}$ Skyler, 'A Reject Review', Reading the Maps URL: http://readingthemaps.blogspot.com/2008/04/rejectreview.html accessed on 4 Jan 2009

${ }^{4}$ Jamieson, 'Private Life' 2008
} 
concepts of 'whānau', were much like those written by Māori short fiction writers in Aotearoa. In Breadfruit, Vaite touches on issues such as superstitions, relationships, sexuality, and class. In her novels there is little written about non-indigenous people apart from the characters cast as employers and there appeared to be an underlying notion that the protagonist's community survives as a separate Tahitian society living juxtaposed with the colonial 'French' society. The attitudes towards whānau in Vaite's book shows a strong similarity to those found in fiction written by Māori women; for instance, personal titles such as aunty, cousin and Mamie are given to people in accordance to age rather than biological lineage. Likewise, characters in short fiction written by both Māori and Tahitian writers also regard their deceased with great respect; and in both cultures the whānau is predominately their community as well ${ }^{5}$.

I was trying to identify what it was about Vaite's fiction and most certainly, Tawhai's fiction, that made me want to celebrate their work while at the same time try to protect the stories from what appeared like judgmental criticism from literary reviewers. At the time of producing this research there did not appear to be any scholarly criticism available, so I sought an alternative way in which to read and discuss Tawhai's work. The approaches of post-colonialism were helpful but post-colonialism often compared Māori literature to non-Māori literature to highlight a point of difference. I was looking for an approach that focused primarily on contemporary Māori short fiction that paid particular attention to what made short fiction written by Māori writers so unique and distinct from other short fiction written in Aotearoa. An approach that allowed me to

\footnotetext{
${ }^{5}$ An example of the a whānau also being a character's community can be seen Whiti Ihimaera's collection of short stories called Pоипати Роипати, where most of the stories are set in Waituhi and contain multiple immediate and extended family members as additional characters. The whānau/community example is also seen in Patricia Grace's, Potiki, where many of the same whānau or hapu live within walking distance of each other.
} 
have an exchange of ideas about the content of Tawhai's work and to critique it on its own merits, endorsing contemporary Māori literature to be recognised as its own entity rather than housing it under the umbrella of national literature.

The literary approach had to ideally focus on contemporary Māori fiction so that I could apply it to Tawhai's work. In failing to find any substantial amount of research completed on literary approaches that primarily looked at Māori literary practices and Māori writing I came across a book called American Indian Literary Nationalism ${ }^{6}$ that featured many of the ideas and methods that I wanted to apply to Māori literature. After further reading and consideration I believe that the foundations from which American Indian Literary Nationalism are based, suited Tawhai’s work best.

In this research I propose to look at the works of Alice Tawhai and use her stories as an example and argument for Māori Literary Nationalism. I will be doing close readings of Tawhai's short stories from both of her collections. Through these close readings I will also propose that a practice such as Māori literary nationalism will offer Māori people a different way of reading and discussing Alice Tawhai's short stories and possibly, all contemporary Māori short fiction. Introducing new writing and a new theory into such a contentious field will allow Tawhai's work as well as perhaps all contemporary Māori literature to be comprehended, distinguished and approached from another perspective that will subsequently enable Māori literature to be recognised as a literature in its own right rather than just a division of New Zealand literature.

${ }^{6}$ Weaver. Jace, American Indian Literary Nationalism (Albuquerque, University of New Mexico: 2005) 
This research will primarily be text-based. Alice Tawhai's collection will be the main focus of the study, but I will also draw on other Māori fiction to show how contemporary Māori fiction has developed in Aotearoa since Witi Ihimaera produced the first published collection of short fiction in 1972. Tawhai is a contemporary Māori writer who published her first collection of short fiction in a book called Festival of Miracles (Huia, 2004). Tawhai went on to publish her second collection, Luminous, (2007) which was shortlisted for the 2008 Montana New Zealand Book Awards. Her work gained a lot of recognition and was acknowledged in various literary events and media, and was included in an anthology edited by Fiona Kidman called, The Best New Zealand Fiction: Volume $3^{7}$. However, the extent of literary criticism published about Tawhai's work is very limited and at coming in the form of literary reviews published in national publications and online.

There will also be a comparative element to this thesis as I apply theories from American Indian literary nationalism to Māori literature. The American Indian Literary Nationalism (2005) publication has theories and concepts that provide a substantial foundation on which to base my study. This publication is made up of a series of contributions by some of the leading Native scholars from the United States of America. It is the product of many years of Native literary criticism and research on American Indian literature.

The contributions made to American Indian Literary Nationalism by Jace Weaver, Craig S. Womack, Robert Weaver, Simon J. Ortiz and Lisa Brooks are reflections on how American Indian literary nationalism is an essential practice that benefits both Native literature and Native readers. Ortiz who is recognised by scholars and critics as a major

${ }^{7}$ The Best New Zealand Fiction: Volume 3, ed. Fiona Kidman (Auckland: Vintage, 2006) 
contributor to Native literature sums up in the 'Forward' of American Indian Literary Nationalism the importance of Native literature:

The consciousness of ourselves as indigenous cultural beings is very important to our Existence as speaking-writing Indigenous people. In fact, cultural consciousness as Indigenous people is the bottom line. And that, more than anything else, has to do crucially with our cultural sovereignty as Indigenous people. While it's true to some extent — some people will even say many Native languages have completely vanished — that Indigenous languages are spoken less than they were five hundred years ago, there is, nevertheless, a vital sense of cultural continuity maintained because of Indigenous cultural consciousness. "Indians are still Indians," ... identity has to do with a way of life that has its own particularities, patterns, uniqueness, structures, and energy. ${ }^{8}$

It is Ortiz's comments that I believe align with the idea of Māori writing as a form of consciousness. Different experiences of Māori people portrayed through narratives such as Tawhai's demonstrate a growing understanding of Māori people who have adapted to a lifestyle we now share with non-Māori people, through the use of literary techniques. As with the cultural consciousness of the American Indians that Ortiz mentions, the same applies to Māori in that "Māori are Māori" and our identity is constituted through our own particularities, patterns, uniqueness, structures, and energy.

In the following chapters I will be doing a gradual expansion of both short stories and the possibilities in which Māori literary nationalism could be practiced and developed. The first chapter aims to evaluate the concept of the "insider's view". I will apply and contrast

\footnotetext{
${ }^{8}$ Simon J. Ortiz, 'Forward: Speaking-Writing Indigenous Literary Sovereignty' in American Indian Literary Nationalism (Albuquerque, University of New Mexico: 2005) p. xi
} 
a single concept with a single story. The reason for choosing a single story for the close reading is to try and maintain a focus on how essential a concept like the "insider's view" is to the text when using an approach like Māori literary nationalism, without being distracted by multiple storylines. The second chapter will take a more expansive view that will include stories from Tawhai's first collection of short stories. Growing from the idea of a single concept, I will start to broadly encompass the idea of nationhood and its relevance to the proposed approach of Māori literary nationalism. I will explore the stories to highlight a point of difference, not by comparing the text to non-Māori texts, but to other Māori literature and artistic forms that have endeavored to reflect Māori ideals. In the final chapter I will examine if an approach like Māori literary nationalism can work and be understood at an international level or under the umbrella of Indigenous nations. Through a close reading of selected stories in Tawhai's second collection I will investigate whether an approach like Māori literary nationalism is exclusive to Māori or if in fact it can be adapted to other Indigenous literary theories, just as I have adopted the knowledge and structure from American Indian literary nationalism for my own purposes.

Before delving into the close readings it is important to understand how Māori short fiction has developed and where it is possibly heading, in Aotearoa. Throughout the remaining section of the introduction I will be briefly discussing the history of Māori short fiction and its relationship to contemporary Māori short fiction. I will also be looking at the literary criticism that surrounds Māori fiction, sometimes drawing on other Indigenous literatures to try and identify commonalities. I refer to "contemporary" as the years from Tawhai's first publication in 2005 through to the present day, keeping Tawhai's work central to the research. 
In the 1970s a grouping of Māori writers contributed extensively to literature written and published in English, making a significant impression on Aotearoa fiction. Literary critic Suzanne Romaine notes that the:

flourishing of Māori artistic, cultural, and political expression that began in the 1970s has since become known as the Māori Renaissance. During this time a significant body of fiction written in English by Māori novelists such as Patricia Grace, Keri Hulme, and Witi Ihimaera began to emerge. The appearance of these works heralded a significant shift in New Zealand's literary tradition, from its Eurocentric foundations to a postcolonial perspective that privileges the "insider" or indigenous point of view. ${ }^{9}$

In literary terms, the Māori Renaissance was an artistic movement that produced a relatively small amount of short fiction in comparison to the amount of work produced before and during that time by non-Māori New Zealand writers. The work produced by such writers as Grace, Hulme and Ihimaera set a standard for Māori writing that reading audiences became familiar with; seeing Māori people being portrayed in Māori communities or dealing with social/political movements that affected Māori people. Through their books they covered, as Romaine mentioned, "Māori artistic, cultural, and political expression[s]" of Māori attitudes and lifestyles.

These were writers who had published books. But before this short stories or fiction produced in Aotearoa by Māori writers was often seen in a government magazine called Te Ao Hou. Te Ao Hou:

\footnotetext{
${ }^{9}$ Suzanne Romaine, 'Contested Visions of History in Aotearoa New Zealand Literature: Witi Ihimaera's The Matriarch, The Contemporary Pacific, Volume 16, Number 1, Spring 2004, 31-57
} 
was published from 1952 to 1976 by the Māori Affairs Department in New

Zealand Aotearoa. According to its first editorial, Te Ao Hou aimed "to provide interesting and informative reading for Maori homes ... like a marae on paper, where all questions of interest to the Maori can be discussed." It was in the 1970s that there appeared to be a grouping of Māori writers that contributed extensively to literature written and published in English, making a significant impression on New Zealand fiction. ${ }^{10}$

This magazine was the first way of reading Māori writers on a regular basis. It included writers like Witi Ihimaera, Patricia Grace and Jacqueline Cecilia Sturm (J C Sturm). However, in the late 1940s Sturm's poetry was published in student newspapers and the Review and by 1966 she had written a collection of short fiction, but no one wanted to publish it and as family commitments increased her ambition to get her collection published had been put to the side. Sturm published her first collection of short fiction in 1983 titled, The House of the Talking Cat. ${ }^{11}$ These early Māori short fiction writers set precedence for a Māori writing style in Aotearoa. From the 1940s through to the 1980s Māori writing was identified as part of the Māori Renaissance and like all renaissance movements, it has since grown, changed and developed into something else.

Short stories by writers such as Alice Tawhai are an example of how Māori literature has shifted in narrative style from the Māori Renaissance narratives. Tawhai and a few of her writing contemporaries like Paula Morris and Kelly Ana Morey as well as the many writers who were published in Huia Short Stories 6 and Huia Short Stories 7 were starting to write without Māori people necessarily being their main focus. Tawhai's

\footnotetext{
${ }^{10}$ Te Ao Hou: The New World, [online] URL: $\underline{\text { http://teaohou.natlib.govt.nz/journals/teaohou/index.html }}$ accessed 19 September 2009.

${ }^{11}$ J C Sturm, New Zealand Book Council [online] URL:

http://www.bookcouncil.org.nz/writers/sturmjc.html accessed 2 October 2009
} 
fiction includes stories about Asian, Pacific and Italian families and even a magical creature from Greek mythology.

Narratives were no longer focusing on the Māori characters and situations as they were in earlier writings of the Māori Renaissance. The narrative shift was partly due to the absence of 'Māori markers'; markers that helped identify fiction as being Māori fiction. These Māori markers were the aspects that helped create a distinct style that set Māori fiction apart from mainstream New Zealand literature. Most of these distinctions are seen through various portrayals of cultural and social themes. The term Māori markers are much like the commonly referred to term Māoridom or Māoritanga, which has been debated as Māori Marsden (1975):

saw Maoritanga as the "corporate view that Maoris hold about ultimate reality and meaning." Rangihau (1975) added relish to the debate. For him the term Maoritanga was invented by Pakeha as a means of positioning Maori as a homogeneous grouping rather than affirming the diversity of whanau (extended family), hapu (subtribe), and iwi (tribe) identification. ${ }^{12}$

Māori markers are distinctions that are often associated with generalised or stereotypical Māori behavior and characteristics. This might lead us to believe that Māori markers have been "invented by Pākehā as a means of positioning Māori as a homogeneous grouping." 13 If this is the case, and it appears to be so, it is possible for mainstream literary critics to overlook features within the text that do not fall into those categories. This may be because mainstream critics have had less of a personal understanding of

\footnotetext{
${ }^{12}$ Leonie Pihama, Fiona Cram, Sheila Walker. Creating methodological space: A literature review of Kaupapa Maori research Canadian Journal of Native Education. Edmonton: 2002. Vol. 26, Iss. 1, p. 30-43 (14 pp.)

${ }^{13}$ Pihama, Cram, Walker, (2002)
} 
Māori experiences and perspectives than perhaps a Māori critic. Another reason may be that the reviewer has to write in such a way that their target audience will understand and continue to be interested. This is where an approach like Māori literary nationalism would benefit Māori readers because it encourages you to look at the whole piece of writing where the cultural markers may be obscure or in some cases, non-existent.

In looking for other ways in which Tawhai's works have been read, my literary exploration has in large come from literary reviews. The upside of literary reviews is that a wider reading audience is acknowledging Tawhai's work, but the downside is that reviews do not offer an in-depth analysis of the text like literary criticism does. Even with the increase of Māori literature, it is fair to say that the majority of literary reviews produced in Aotearoa are for a mainstream audience. There are numerous reviews conducted by non-Māori reviewers that have looked at Māori short fiction in comparison to those by produced by Māori literary reviewers.

To try and get an idea of how literary reviewers in Aotearoa were portraying Māori short fiction during the time that Tawhai's collections were being released, I will be looking at reviews written by two literary reviewers. There have only been two other collections of short fiction released by a single Māori writer between 2005 and the present day. Literary reviewer David Hill discusses Patricia Grace's collection, Small Holes in the Silence (2008):

The tone comes also from those spoken voices: dialogue among characters; yarns from narrators; memories of people past, present and timeless. From the ability men and women show to sit still, watch and listen (ref the title), "as though waiting for some wild, clawed thing”. And from the way Grace's frequently 
anonymous protagonists hover on the edge of myth and metaphor. Their bedroom fills with stars; they give themselves to a meeting-house carving; they bad-mouth the moon and suffer for it. ${ }^{14}$

Hill praises Grace's collection of short stories and discusses the fact that her stories often interweave or allude to Māori mythology. Hill also takes care to point out the distinctive features or "Māori markers" that feature in Grace's stories. This makes it clear to anyone who may not have read her work that marae-based narratives are a common feature in her stories. She also employs key language features that make the narratives unique to Aotearoa while at the same time giving a Māori voice to characters. In that one paragraph Hill mentions the "meeting-house carving" in his review, the meeting house is assumed to be a wharenui (a housing structure unique to Māori culture). The wharenui is an example of a "Māori marker" in fiction. He also comments on the language used in Grace's fiction with its use of both te reo Māori and English and enforces that many Māori words have become so familiar in Aotearoa English that they do not need to be translated. One would assume that Grace has used Māori words within the content of her work in such a way that a translation is not needed to understand the general meaning of what she is trying to say.

I remember the jaw-dropping stupidity of one reviewer who charged the author with "rudeness" for including fragments of te reo in an earlier book without providing English translations. (Pause here to strike head rhythmically against wall.) In this collection, the two languages fit like a template for a real One NZ. ${ }^{15}$ The use of te reo Māori in English fiction has developed into an iconic feature, much like the haka has become to the All Blacks rugby team. It begs the question; would the haka

\footnotetext{
${ }^{14}$ David Hill, 'Book Review: Small Holes in the Silence' in New Zealand Listener September 30-October 62006 Vol 205 No 3464

${ }^{15}$ Hill, 'Book Review'
} 
be performed if there were no Māori players in the All Blacks? Likewise would it be acceptable if non-Māori used a mixture of te reo Māori in their fiction written in English? The fact is there are many Māori words included in and regarded as Aotearoa English as seen in The dictionary of New Zealand English (1997) ${ }^{16}$ and ${ }^{17}$ The Reed dictionary of New Zealand English (2001).

Having an Aotearoa/New Zealand standard of language commonly used in fiction, eliminates what is unique about te reo Māori and could ultimately change the significance of some Māori words because they are so frequently used in English text. Trying not to stray too far away from the topic, but a small example of this sort of misinterpretation was seen at the new Capital and Coast Wellington Hospital where a room had a sign above the door that said "Whānau Room". Later there were complaints made to the hospital staff that Māori families who were visiting loved ones "had more or less moved in". What the sign for the room had meant to say was "Waiting Room". Substituting an English word for a Māori word in an attempt to be more culturally and politically considerate, runs the risk of awkwardness on behalf of the host if the concept surrounding the te reo Māori is not understood. The importance of language is as Jace Weaver explains:

[W]e understand within a colonial society the function of the colonizer's language is to promote intellectual and cultural domination. For Natives, English and French are imperialist languages. Although most of us speak one or another of the

\footnotetext{
${ }^{16}$ The dictionary of New Zealand English: a dictionary of New Zealandisms on historical principles, ed. H.W. Orsman (Auckland: O

${ }^{17}$ The Reed dictionary of New Zealand English: the first dictionary of New Zealand English and New Zealand pronunciation, general editor, H.W. Orsman; revising editor, third edition, Nelson Wattie (Auckland: Reed, 2001)
} 
colonizers' languages, it does not mean that we embrace all his culture or ideology. ${ }^{18}$

Much like Grace's work, Tawhai's uses language to create the personalities of her characters and to create a sense of belonging for each of the stories to her collections. With subtle dialect changes in Māori words, a Māori reader could possibly take a guess at where that person is from. For example, in some parts of Aotearoa certain iwi use the ' $h$ ' in particular words, whereas in other parts of Aotearoa, 'wh' is used; most recently seen in a debate over the replacement of the letter ' $h$ ' in the name Wanganui, changing it back to Whanganui:

Historical evidence has shown that early settlers clearly intended the name of the city to be derived from the Maori name for the river, and consistent modern usage of the language showed the spelling should be Whanganui, not Wanganui. ${ }^{19}$

Te reo Māori words used in English writing is an important feature and one of the most obvious markers of Māori writing used in Grace's short stories and in some stories of Tawhai's. However, there are many narratives throughout both of Tawhai's collections where language and voice are not Māori at all.

Paula Morris, who happen to be the third Māori writer to have released a collection of short stories in 2009 called, Forbidden Cities, bases many of her stories in international settings, so the "Māori markers" are practically non-existent. The literary reviewer gives Morris' narratives an Aotearoa familiarity by writing about Morris previous works.

\footnotetext{
${ }^{18}$ Jace Weaver, 'Splitting the Earth: First Utterances and Pluralist Separatism' in American Indian Literary Nationalism (Albuquerque, University of New Mexico: 2005) p. 32

${ }^{19}$ Dave Chowdhury 'Laws: Wanganui upset over 'h' decision', The Dominion Post, 17 September 2009
} 
It is interesting to see that Rangatira, one of the stories most full of the past and memories of the characters, is already being developed into a novel length version. Set in 1895, this historical novel will represent another change of direction for Morris, who surprised critics who read her first novel, Queen of Beauty, as a study of Maori identity in a global context by setting her third, the satirical chick-lit parody Trendy But Casual, entirely in New York. In between, she published the brilliantly complex, noir-esque thriller Hibiscus Coast, set in an Auckland connected both in terms of the plot and her depiction of the city with the "floating worlds" of contemporary Shanghai - an Auckland with even more complicated intersections of race, class, values, backgrounds and personal relationships than you get at a New Yorker's garden party. ${ }^{20}$

Even if the Māori markers were not present in Morris' fiction, the literary reviewer was sure to make that connection to Aotearoa through her review, much like David Hill who was sure to mention something about Grace's work that had a sense of "Māori-ness". For Morris it was the reference to her short story "Rangatira". However, Morris is dissimilar to Grace, yet similar to Tawhai, is through her depictions of other international peoples and situations. Morris tells stories about people "from Sunset Boulevard to the beaches of Auckland, from the Bund in Shanghai to the banks of the Danube."21 Tawhai also portrays people from other countries without having any identifiable Māori markers present in her stories. Grace and Morris both received favourable reviews about how their characters were unique in their own way and not unique because they were thought to act as a representation of particular people.

${ }^{20}$ Anna Jackson, 'Around the World', The Listener October 18-24 2008 Vol 215 No 3571

${ }^{21}$ Jackson, 'Around the World' (2008) 
The reviews written in national magazines and on websites about Tawahi's fiction were few, but significant. Her stories are new and exciting and depict Māori people in all their forms; class, gender, and social positions. She explores a variety of environments that are populated mainly by Māori people within Aotearoa. Tawhai broaches a social territory that few non-Māori writers pursue, possibly because they feel they may come across as inauthentic or be open to criticism from the people they are trying to represent. Journalist Caroline Courtney, ${ }^{22}$ who published an article "Māori in the Middle" in national magazine North and South, had no problems voicing her opinion about Māori and how they are represented in mainstream society. She explored the idea of how some Māori now stand in the class system within Aotearoa. The word "middle" in the title of the article is a play on words for middle class, an idea that implies that until recently Māori had otherwise been working class. The magazine appears to makes little or no marketing attempt to target a general Māori audience so it could be assumed by the content of the magazine that its target audience is Pākehā middle-class, corporate or retired readers.

Through contemporary literary material such as magazines it can be observed that the readerships or at least the perceived readerships in Aotearoa differ between Māori and non-Māori. Compared to the history of literature written in English, Māori fiction has been around for less than a century. However, Māori are writing, and the work that is being produced is not a direct reflection of an English tradition, but a technique used to portray a Māori expression.

Reviews written about each of Tawhai's publications, Festival of Miracles (2005) and Luminous (2007) varied from complimentary to stereotypical. The snapshots of life that

\footnotetext{
${ }^{22}$ Caroline Courtney, 'Maori in the middle', North and South (June 2008) 267: pp. 36-46
} 
Tawhai creates in her work are described by literary reviewers as "stories expose the dark underbelly of 21st-century New Zealand life",23, with characters that live in the "margins of life",24, "[settings that are] readily recognisable, but it also made me feel a little uncomfortable" 25 and as Philippa Jamieson pointed out about the social underbelly characters in Tawhai's stories, "many are Maori"26. These reviews of Tawhai are examples of how perceptions surrounding Māori living in Aotearoa are aligned with representations depicted in articles such as Caroline Courtney's "Māori in the Middle"27. Other examples of headlines that appear in national newspapers portraying Māori people as people who waste the taxpayer's money with their culture practices, "Maori rites cost taxpayers more"28; perpetrators of domestic violence, "Once Were Warriors watched before death",29; child abuse, "Family faces up to its shame",30; unemployment, "Key [Prime Minister John Keys] calls Maori job summit" ${ }^{31}$; and trouble-makers over land and foreshore rights, "UN Man 'stunned' to find Maori in cities.",32 Literary reviews written about Tawhai's narratives were being represented as reflections of how mainstream media depicted and generalised Māori people.

Through her short fiction, Tawhai touches on the ideas, values and ethics that are unique to Māori. However, without an adequate literary framework Tawhai's work, as well as all other Māori literature, will continue to be as Cherokee scholar Jace Weaver puts it,

\footnotetext{
${ }^{23}$ Jamieson, 'Private Life' (2008)

${ }^{24}$ Wareham Leonard, 'Festival of Miracles by Alice Tawhai' (2009)

${ }^{25}$ Skyler, 'a reject Review' (2009)

${ }^{26}$ Jamieson, 'Private Life' (2008)

${ }^{27}$ Courtney, 'Maori in the middle' (2008)

${ }^{28}$ Ruth Hill, 'Maori rites cost taxpayers more', The Dominion Post, Tuesday, 13 January 2009 The Dominion Post is one of the country's biggest newspaper circulations. This article describes how the number of spiritual ceremonies has increased from previous years costing the taxpayer more money to accommodate them.

29 'Once Were Warriors watched before death', The Dominion Post, Wednesday, 12 November 2008

${ }^{30}$ Keri Welham, 'Family faces up to its shame', The Dominion Post, Thursday, 20 November 2008

${ }^{31}$ Vernon Small, 'Key calls Maori job summit', The Dominion Post , Saturday, 24 January 2009

${ }^{32}$ Tracy Watkins, 'UN Man 'stunned' to find Maori in cities', The Dominion Post, 6 April 2006
} 
"approached within an already established theory, and the implication is that the worth of the literature is essentially validated by its demonstrated adherence to a respected literary mode, dynamic, or style. ${ }^{33}$

One possible way of looking at Tawhai's work is to draw on techniques used in other methodologies that serve Māori literature in the best possible way for the text and the critic. In proposing an approach for a new way reading Māori text, it has to be asked what factors would be considered, whose interest this practice would serve, and how would it be implemented. One of the founding concepts would be the "insider's view" in an effort to keep Māori central to discussions. In an article by Suzanne Romaine, she speaks of, "the insider" or "indigenous point of view" articulated by Māori writer Witi Ihimaera $^{34}$. Ihimaera stated, “They're [post-colonialism] international constructs. They're part of a need to look at a work from the outside. What matters to me is the view from the inside out. ${ }^{, 35}$ Indigenous artists such as Ihimaera and Patricia Grace have not only expressed this view for many years, but so too have other nations that have either been colonised or are ruled by a governing authority. Kenyan writer, Ngugi wa Thiong'o, expressed a similar view saying, "Why can't African literature be at the centre so that we can view other cultures in relationship to it?"36 This concept marks a way of thinking, a concept that was explored recently in American Indian Literary Nationalism (2005). Adapting the founding principles of American Indian literary nationalism and applying them to Māori literature gives a possible new way of reading Māori text. Like American

\footnotetext{
${ }^{33}$ Weaver, (2005) p. 27

${ }^{34}$ Romaine, (2004)

${ }^{35}$ Witi Ihimaera interviewed by Juniper Ellis. 'The Singing Word: Witi Ihimaera interviewed by Juniper Ellis', Journal of Commonwealth Literature 34.1, 1999, 176

${ }^{36}$ Ngugi wa Thiong'o. Decolonising the Mind: The Politics of Language in African Literature (London: James Currey Ltd., 1981) p.89
} 
Indian literary nationalism, the suggested new approach would be one of Māori literary nationalism.

What the approach of Māori literary nationalism would look like is still in the developmental stages. As I mentioned earlier, this methodology is not starting at ground zero, but rather it is an accumulation of critical techniques, such as the insider's view, that have been developed and used in other literary approaches and frameworks. The grouping of these techniques and literary methodologies would be gathered under the umbrella of Māori literary nationalism and would therefore generate another step forward in continuing Māori intellectual accreditation. Gerald Taiaiake Alfred affirms this notion when he discusses contemporary native politics in Canada and the United States:

A real Indian intellectual is proud of our traditions and is willing to take a risk in defending our principles ... The traditions are powerful, real, and relevant. As intellectuals we have a responsibility to generate and sustain a social and political discourse that is respectful of wisdom embedded within our traditions; we must answer from within those traditions, and present them in ways that preserve the integrity of languages and communicative styles. Most importantly, as writers and thinkers, we should be answerable to our nations and communities.

Alfred articulates an assertiveness of progressive action that he wanted to be acknowledged, in particular, by those native scholars that were progressing in Native studies. These aspirations are suggestions that Māori literary scholars may consider. For a Māori critic or to be consciously aware in acknowledging their Māori heritage and their own understanding of literature or as Robert Warrior explains:

...privileging Native voices was not a matter of infusing Native perspectives with infallible access to truth, but a recognition of the need to be methodologically 
self-conscious in attending to perspectives that had been ignored, debased, discounted, and marginalized. ${ }^{37}$

The reader must also be aware of what other Māori scholars are saying and be open to dialogue surrounding Māori texts. American Indians have already begun the process of sharing their criticism in a learning space, "Native Americans need the experience of making our own mistakes in literary criticism. Even a faulty criticism is more interesting than a 'correct' one directed by a literary overseer. This is what sovereignty and selfdetermination is all about." ${ }^{, 38}$ These processes also have to occur among Māori scholars, critics and readers so that we can develop the practice.

Being aware and keeping up to date with research written by Māori critics is an important process in seeing how a Māori understanding is developing through scholarship. Although there are limited Māori critics who specialise in literature, there is ample Māori criticism that can be applied to literature from critics and scholars such as Jon Battista, Cathie Dunsford, Ranginui Walker, Alice Te Punga Somerville, Linda Tuhiwai Smith, Ahukaramu Charles Royal, Leonie Pihama, Reina Whaitiri, Merimeri Penfold, Ngahuia Te Awekotuku, and many more. Alice Te Punga Somerville stated that, "While there is increased academic interest in Maori writing ... little of the current scholarship has attended self-consciously to the issue of critical methodologies that pertain to this material." ${ }^{39}$ Ultimately, Māori literary nationalism would aim for similar goals as the model set by the Native Americans. Their goals for American Indian literary nationalism

\footnotetext{
${ }^{37}$ Robert Warrior, 'Native Critics in the World' in American Indian Literary Nationalism (Albuquerque, University of New Mexico: 2005) p. 195

${ }^{38}$ Weaver, (2005) p. 37

${ }^{39}$ Alice Te Punga Somerville, 'Nau te rourou, nau te rakau: the oceanic, indigenous, post-colonial and New Zealand comparative contexts of Māori writing in English (Dissertation abstract)', online URL: http://proquest.umi.com.helicon.vuw.ac.nz/pqdweb?did=1192182141\&sid=1\&Fmt=2\&clientId=7511\&RQ T=309\&VName=PQD accessed 21 Jan 2009
} 
include "the study and teaching about Native peoples from an indigenous perspective and supporting Native Americans in their struggles. It "provides a space for further dialogue within a framework that privileges the Indigenous presence. ${ }^{, 40}$ Catering for contemporary Māori literature may include drawing on methodologies constructed primarily for a colonial discourse or as a reviewer of Linda Tuhiwai's book, Decolonizing Methodologies: Research and Indigenous Peoples states "it is not enough to simply acknowledge colonial domination; researchers must also abide by Indigenous perspectives and sources so as to prevent the further corruption of tribal histories and achieve the empowerment necessary" ${ }^{\prime 41}$ for this new purposed methodology. Māori Literary Nationalism is an approach that would be especially pertinent to Tawhai's work because of the content that Tawhai chooses to cover. Tawhai's work is mainly made up of contemporary social-realism, a fictitious reflection or portrayal of contemporary social-history.

By emphasising that Māori readers need to take more of an active role in participating with an approach such as Māori literary nationalism; does not disqualify non-Māori readers in offering substantial literary criticism. However, non-Māori readers and critics cannot offer a Māori perspective. They can use the tools of the theory to offer an approach of cultural empathy. For non-Māori critics who have studied Māori literature, they have discovered that they "cannot talk of (published) Māori criticism or even something different. There has been objection of new indigenous literatures using the

\footnotetext{
${ }^{40}$ Linda Tuhiwai Smith, Decolonizing Methodologies: Research and Indigenous Peoples (Dundedin: Zed Books, 1999) p. 6 cited in Jace Weaver, 'Splitting the Earth: First Utterances and Pluralist Separatism' in American Indian Literary Nationalism (Albuquerque, University of New Mexico: 2005) p. 43

41 'Book Review' American Indian Quarterly 29 (2005) p. 290
} 
criteria applied to criticism of English literature. ${ }^{42}$ However, for a Māori or Indigenous critic the idea of Ihimaera's view "from the inside out" would primarily give the insider's view a critique and draws on Western methodologies as secondary techniques

Native American writer Paula Gunn Allen reiterates, "that the study of non-Western literature poses a problem for Western readers, who naturally tend to see alien literature in terms that are familiar to them, however irrelevant those terms may be to the literature under consideration.” Much like Panny’s cultural-historical readings of Māori text, a critic will always bring their own cultural background and values when approaching another culture's text, which can be limiting to the text's analysis. Māori readers also emulate Panny's concern, not the concern that Māori have difficulties approaching a Pākehā perspective, but how we see ourselves in Pākehā writing. In a book called, Where's Waari?: A History of Māori through Short Story, Ihimaera writes:

Indeed, stories about Māori have presented writers both Māori and Pākehā with a problematic task: to articulate how we are to the other. But what we as readers see in the stories is also problematic, and depends on the personal and cultural background we bring to the reading. ${ }^{43}$

The way that Māori currently see themselves represented, or rather mis-represented, through literature written by non-Māori writers, is reason for concern. Māori and Indigenous characters in narratives are not as flexible as our Pākehā counterparts. Acts of colonisation have distributed and located European people throughout most countries in the world. Indigenous people will always be associated with their country of origin and will therefore always be affiliated to particular lands without variations.

\footnotetext{
42 Jane McRae, 'Patricia Grace - Interviewed by Jane McRae' in Judith Dell Panny, 'A Cultural-Historical Reading of Patricia Grace's Cousins' Kōtare 6 (2006)

${ }^{43}$ Witi Ihimaera, Where's Waari?: A History of Māori through Short Story (Auckland: Reed Publishers, 2000) p. 10
} 
For non-Indigenous writers to imagine Indigenous characters out of context, or placing a foreign character amongst the Indigenous people and presuming their behavior through narratives can risk enforcing stereotyping and generalisation in an attempt to make things more believable. For Melissa Lucashenko an Australian aborigine writer:

If you decide to write a story set in Cairns, and populate it with Aboriginal people drawn from your imagination, you are writing of the Yidingi. If your story begins in Mount Isa and shifts to Alice Springs, your characters are Kalkadoon, or Arrente...There is no "fiction”. It doesn't matter where you locate your story, there will always be a specific group of local Aboriginal people who have a stake in what you think, say and write." 44

This is seen when a writer has placed a foreigner into an Indigenous setting and depicted presumed behaviour and practices. An example in Aotearoa literature is in the novel, $M r$. Pip, written by Lloyd Jones who won the 2007 Montana Book Awards and was a finalist for the Booker Man Prize for the mentioned book. Although Mr. Pip is not a Māori story, the story is about an Indigenous girl and set in Papua New Guinea during a time of national conflict. Dr. Selina Marsh wrote an article that critiqued the authenticity of Jones' book and she believing that the text suffers some "significant failures of imaginative empathy or accuracy that renders it unconvincing." ${ }^{45}$ Australian historian, Inga Clendinnen also supports this notion by reaffirming that a novelist needs more than imaginative empathy to do a reasonable job of depicting "the other" in her essay, The History Question: Who Owns the Past. ${ }^{46}$ The "other" that is referred to is not "other

\footnotetext{
${ }^{44}$ Melissa Lucashenko, 'Muwi muwi-nyhin, binung goonj: boastful talk and broken ears' WQ: Write Queensland July (2009)

${ }_{45}$ Chris Price, 'Te Writing is on the air (w)here the wall once was', New Zealand Book Council [online] URL: http://www.bookcouncil.org.nz/writers/Going_West_keynote.pdf , accessed on 15 Jan 2008, pp. 7-8 ${ }^{46}$ Inga Clendinnen, 'The History Question: Who Owns the Past' in Quarterly Essay 23 (2006)
} 
characters" in fiction, but the "other" culture, which is not, the author's own. There are many reviews and critiques of $\mathrm{Mr}$ Pip, but as Clendinnen notes, "There is always one counter-story, and usually several, and in a democracy you will probably get to hear them, ${ }^{, 47}$ signifying how various literary theories and perspectives on literature involving Indigenous characters, politics and lifestyles must be articulated to vindicate a more perceptive understanding.

The content and subject matter of what is depicted in Tawhai's work can be seen as a reflection of "social-realism"; however, it should not be confused with a reality of Māori culture. In critiquing Māori literature "literary critics make claims about social realities in the context of their criticism, they have a responsibility to those they are choosing to represent in print." ${ }^{48}$ For non-Māori reviewers or critics to discuss storylines or situations unfamiliar to them may be difficult or make them feel uncomfortable if they are to broach subjects that critique a culture that challenges their own understanding of the content. However, this level of understanding is not only limited to non-Māori critics, it can in some cases affect those critics who identify as Māori. The difference between the two is that a Māori critic is able to share their experience and understanding of being Māori and how they relate to the text, again, generating dialogue in a convivial space for Māori critics.

One of the challenging aspects that I have had to consider in suggesting an approach like Māori literary nationalism, are the connotations around "nationalism". To suggest a

\footnotetext{
${ }^{47}$ Penguinunearthed, 'Review - The History Question: Who Owns the Past' [online] URL: http://penguinunearthed.wordpress.com/2006/12/31/review-the-history-question-who-owns-the-past/ accessed on 15 Jan 2008

${ }^{48}$ Craig S. Womack, 'The Integrity of American Indian Claims' in American Indian Literary Nationalism (Albuquerque, University of New Mexico: 2005) p. 94
} 
practice that incorporates the word "nationalism" can infer confrontational implications of taking a nationalistic stand, especially in an age when New Zealand is making an effort with biculturalism and honoring the Treaty of Waitangi. For this discussion biculturalism is referred to, instead of multiculturalism, to ascertain the notion of Māori and non-Māori. At an academic level the, "position within their own societies of 'native' intellectuals who have been trained in the West has been regarded by those involved in nationalistic movements as very problematic." 49 Speaking on the topic of Māori Literary Nationalism Māori at the Māori National Writers Hui, Māori scholar Dr Te Ahukaramū Charles Royal stated at the hui, "I am deeply suspicious, of the word "Māori" and the word "Nationalism". ${ }^{50}$ Royal went on to say that being Māori can come with a lot of "baggage" depending on where you are in Aotearoa, just as much baggage as the word "Pākehā" and his concern was that the word "Māori" would become constricting, rather than liberating. ${ }^{51}$ Lisa Brooks, who wrote the "Afterword" in American Indian Literary Nationalism, also discusses how the word nationalism made her feel uncomfortable because of the connotations of patriotic and jingoism that was associated with that term. She goes on to explain that for her the term "nation" has quite different meanings in English and her Native language Abenaki, the tribe to which Brooks is affiliated with. ${ }^{52}$ There are also multiple possible understandings of the word "nationalism" depending on how flexible you are to alternative definitions.

\footnotetext{
${ }^{49}$ Tuhiwai Smith, (1999) p. 69

${ }^{50}$ Te Ahukaramū Charles Royal, 'Can we Sustain Māori Literary Nationalism', public address at the Māori Writers National Hui, Wellington Town Hall, 19 October 2008

${ }^{51}$ Royal (2008)

${ }^{52}$ Lisa Brooks, 'At the Gathering Place' in American Indian Literary Nationalism (Albuquerque, University of New Mexico: 2005) p. 244
} 
Jace Weaver supports literary nationalism by saying that it is "not a confrontation, not a tearing down, but an up building. ${ }^{, 53}$ Literary nationalism highlights a need for an internal cultural reading to help evaluate a statement already documented through fiction.

Taiaiake Gerald Alfred ${ }^{54}$ also endorses Weaver's comment by stating:

Experience ... has shown that cultural revival is not a matter of rejecting all Western influences, but of separating the good from the bad and fashioning a coherent set of ideas out of the traditional culture to guide whatever forms of political and social development—are appropriate to the contemporary reality. This notion of fashioning a coherent set of ideas can also lean towards an act of selfdetermination and self-representation, which in turn is a step closer to Māori sovereignty. Governing how we see ourselves being represented in literature.

Another way of giving an approach like Māori literary nationalism a Māori focus is by changing the word nationalism to a term like Kaupapa Māori. As Leonie Pihama explains in an educational article Kaupapa Māori:

captures Maori desires to affirm Maori cultural philosophies and practices. In short Kaupapa Maori is about being "fully" Maori. These desires have only rarely been recognised by the mainstream education system that has at various times sought to "civilise," "assimilate," and "integrate" Maori. The struggle by Maori for control over how Maori children and young people are educated has led to the establishment of Kaupapa Maori education initiatives across all educational levels. These initiatives are exemplary in that they reflect Maori aspirations and

\footnotetext{
${ }^{53}$ Weaver, (2005) p. 6

54 Taiaiake Alfred, Peace, Power, Righteousness: ān Indigenous Manifesto (Don Mills, ON: Oxford University Press, 1999), p.84 cited in 'Splitting the Earth: First Utterances and Pluralist Separatism' in American Indian Literary Nationalism (Albuquerque, University of New Mexico: 2005) p. 31
} 
continue to produce bicultural, bilingual, confident, and well-educated Maori. This article outlines the key elements underpinning these initiatives largely through an exploration of the writings that have emerged from Maori education staff and students at the University of Auckland. A self-determination, anticolonial education agenda emerges that is firmly based in Maori language and cultural ways of being. ${ }^{55}$

Although the literary focus would be on Māori, the meanings behind Kaupapa Māori do not translate directly into English and there may be variations in meanings. At least with literary nationalism, American Indians have shown that that particular title for a literary approach is acceptable to practice under.

Basically, an approach like Māori literary nationalism would be looking at the relationship between the text, reader, and practice. Throughout this research I will be exploring Tawhai's text and looking at the possibilities of using tools and techniques that are similarly used in the practice of American Indian literary nationalism. Chapter one, aims to evaluate the "insider's view" for the reader, critic, writer, and text in a single short story written by Tawhai. The second chapter will take a more expansive view to include Tawhai's first collection of short stories and to explore how an approach such as Māori literary nationalism can value the text as being Māori text, rather than text that is a fraction of Aotearoa literature. In the final chapter I will examine if Māori literary nationalism can work and be understood at an international level or whether it would only be relevant within Aotearoa. For this I will focus on Tawhai's latest collection of short fiction. Tawhai's work is the most recent short fiction publication written by a

${ }^{55}$ Pihama, Cram, Walker. (2002) 
Māori writer released in Aotearoa. Her narrative style encompasses the contemporary shift in storytelling that coincides with the evolving artistic Māori movement that has developed since the Māori Renaissance. Through a series of close readings I aim to demonstrate how Tawhai's text can be viewed using a similar structure to American Indian literary nationalism, thereby looking at the works of Alice Tawhai as an example and argument for Māori literary nationalism, as a literature in its own right rather than a subsection of New Zealand literature. 


\section{The insider's view and 'Pale Flower'}

This chapter focuses on the 'insider's view' through a close reading of 'Pale Flower' from Tawhai's first collection, Festival of Miracles (2005). The concept of an 'insider's view' relates to the Māori reader, writer, and text. The binary terminology of Māori and non-Māori will help keep the focus on Māori perspectives. During this analysis any references from a Western, European, English or Pākehā perspective will simply be referred to as non-Māori. Even though Māori Literary Nationalism is modelled on the literary frameworks practiced or considered by American Indian scholars in American Indian Literary Nationalism (2005), one of the founding ideas for Māori literary nationalism will be based on the 'insider's view'.

In terms of the 'Māori reader' the first vantage point will be explore how the text can become a form of resistance; the more a Māori reader is able to understand a text from their own perspective, the less likely they will rely on non-Māori viewpoints and ideologies. An 'insider's view' can assist the reader in relating to the text and encourage an empathetic comprehension to themes portrayed by characters to give a broader understanding. Following the reader, I will discuss the role of the critic as a type of reader and how the 'insider's view' can offer another way of reading. The critic's role in analysing Tawhai's text will look at how some of the more established literary frameworks are unable to freely gain an 'insider's' perspective. 
In looking at the role of the writer, I will examine relationship between the writer and the story 'Pale Flower' as well as looking more broadly at the writer's contribution to other stories she created in both collections. The relationship between Tawhai, her text, and readers of her text is an example of how a voice and perspective can remain Māorifocused. Her creativity will give some degree of accountability of the cultural unique amongst mainstream contemporary short fiction published in Aotearoa. This chapter also attempts to deconstruct the story 'Pale Flower' to gain an insight of how the 'insider's view' can be justified to be an important component for the proposed practice of Māori literary nationalism.

The concept of an 'insider's view' comes from a comment made by Ihimaera; ${ }^{56}$ the actual definition of which has not been formalised but could be a starting point in the formation of Māori literary nationalism. Ihimaera's comment, “They're [post-colonialism] international constructs. They're part of a need to look at a work from the outside. What matters to me is the view from the inside out" ${ }^{, 57}$ can pertain to any work of fiction where a reader or critic can find a commonality to the text or writer. An 'insider's view' differentiates between Māori and non-Māori readers, creating and making distinctions between an empathetic view and a sympathetic view. In Tawhai's 'Pale Flower' the Pākehā mother declares to her husband, 'Your son's brought a Māori girl home for dinner,' as though the protagonist was an object, or something that is fit for consumption. The Māori girl then becomes the outsider in the situation feeling somewhat alien in her own country. An sympathetic view can be constructed or related to by a Māori reader who at one time may have experienced something similar, being made to feel as a

\footnotetext{
${ }^{56}$ Ellis. (1999) p. 176

${ }^{57}$ Ellis. (1999) p. 176
} 
minority or inferior in a situation where non-Māori people and ideals have excluded them. The 'insider's view' will not be as narrow as to always refer to feelings of exclusions; instead they will refer to feelings of inclusion, in being Māori.

\section{Reader}

For a Māori reader an 'insider's view' is a concept that allows Māori readers to reflect upon Māori literature without having to remove themselves from the text. The reader becomes culturally central alongside the characters, situation, or narrator. Māori readers are placed as objective readers when books ascertain non-Māori content. Māori writer, Patricia Grace, made her views clear in an interview when she commented:

Things that make many books dangerous to Indigenous readers: (1) they do not reinforce our value, actions, customs, culture and identity; (2) when they tell us only about others they are saying that we do not exist; (3) they may be writing about us but they are writing things that are untrue; and (4) they are writing about us but saying negative and insensitive things which tell us that we are not good. ${ }^{58}$ When Māori readers are looking at material there is often a tendency to read through western hegemonic ideals and publications allocated throughout non-Māori educational institutions, although the distribution and texts available has changed with the introduction of Te Kura Kaupapa and Whare Wānanga establishments in Aotearoa. With the increase of te reo Māori publications, Māori literature or literature published in te reo Māori is influencing what Māori have available to read.

\footnotetext{
${ }^{58}$ Te Runga o Ngati Awa (1990), Nga Karoretanga o Mataatua Whare. The Wandering of the Carved House, Mataatua. Ngati Awa Research report 2, Whakatane, New Zealand in Linda Tuhiwai Smith, 'Imperialism, History, Writing and Theory' in Decolonizing Methodologies: Research and Indigenous Peoples (Dunedin: Zed Books Ltd., 1999) p35
} 
Māori novelists such as Witi Ihimaera, Patricia Grace, and Keri Hulme were a part of a movement of what is now referred to by critics such as Suzanne Romaine as the Māori Renaissance. This was a time of 'flourishing of Māori artistic, cultural, and political expression $^{, 59}$ that emerged during the 1970s. It would be wrong to assume that Māori writers suddenly became artistic but Māori art began to be recognised as another voice or perspective that differed from popular material published up to that point. This also encouraged readership and literary criticism. Suzanne Romaine argues that 'the appearance of these works heralded a significant shift in New Zealand's literary tradition, from its Eurocentric foundations to a postcolonial perspective that privileges the 'insider' or indigenous point of view. ${ }^{60}$ To a certain extent there is evidence that an 'insider's view' was beginning to emerge in the 1970s, but this was mainly due to the unique point of view Māori writers had to offer. It did not mean the way Māori literature was being read by Māori readers had significantly shifted.

Established in 1991, Huia Publishers is one of the main publishing houses dedicated to producing Māori writing. There are numerous other smaller Māori publishers like Te Wānanga-o-Raukawa and Tōtika Publications who produce education and/or non-fiction books. There have also been self-published Māori writers such as the collection of stories gathered in, He Iti, He Taonga: Taranaki Women Speak, by Kerensa Johnston (2009). Another publication dedicated to Māori fiction and interests was Te Ao Hou: The New World, which was published from 1952 to 1976 by the Māori Affairs Department. ${ }^{61}$ Both larger publishing houses and individuals publishing their own material have contributed to the amount of Māori literature produced.

\footnotetext{
${ }^{59}$ Romaine, (2004) pp. 31-59

${ }^{60}$ Romaine, (2004) pp. 31-59

61 'Te Ao Hou' [online] URL: http://teaohou.natlib.govt.nz/journals/teaohou/index.html accessed on 10 March 2009
} 
There was a need and demand for contemporary material to be published and so:

Robyn Rangihuia [now Bargh] and Brian Bargh set up Huia (NZ) Ltd as an independent publishing company ... The company builds on Robyn's compelling vision of growing the number and range of stories of Māori experiences and language in New Zealand literature. She envisages a world of stories and knowledge that reflect the diversity of Māori experiences and the dynamic cultural interface that is an integral part of the evolution of Aotearoa., ${ }^{, 62}$

Robyn Bargh was determined to start a publishing house because it was important that people, especially children, were able to read literature where they could see themselves. As a child she read the standard material given out as part of the educational curriculum and rarely, if at all, saw Māori people featured. ${ }^{63}$

The 'insider's view' along with the increase of Māori fiction is something that has been developing since the first publications of Māori literature in Aotearoa. Before then, the publications of Māori stories by Māori had been transferred through storytelling (oral tradition) and other forms of artistic mediums such as music, dance and visual arts where Māori culture was at the centre. Huia Publishers was not the only publishing house that believed a change in literary material had to take place in order to support Māori readers. Other organisations like Te Taura Whiri i te Reo Māori: The New Zealand Māori Language Commission and Learning Media also started to produce material in Māori language. Huia remains one of the prevailing establishments that cater principally to Māori writers and readers.

62 'Huia Publishers: Voicing the voices and aspirations of Aotearoa' [online] URL: http://www.nzlive.com/en/huia-publishers accessed 10 March 2009

${ }^{63}$ Robyn Bargh, 'Huia Publishers' in an oral presentation to the Whitireia Community Polytechnic Diploma in Publishing course (Whitireia Community Polytechnic: Wellington, 2005) 
Māori readers have seen an exponential increase in Māori literature since the 1970s and this is particularly prevalent in short fiction. With the increase in Māori literature, comes an increase in the range of subject matter available. Māori writers have often written about the subjects they know best and this is often their environment. Ihimaera depicts a small settlement called Waituhi in his book, Ропати Ропати (1972), the place where Ihimaera grew up. Patricia Grace also writes about her home in the Wellington region in Potiki (1986) and Tu (2004). This in turn appeals to Māori readers, to read material they are familiar with or can make a connection to. At times this content has exposed Māori behaviour and lifestyles, including material some Māori readers would prefer left undisclosed. In Ihimaera's, The Matriarch, the issue of being 'truthful' has been contested for revealing practices or attitudes that had otherwise been unexplored in Māori fiction. Romaine states:

While Ihimaera has drawn fire from both Māori and Pākehā for not being 'truthful' enough to the contemporary Māori realities, Māori elders meanwhile have criticised him for revealing in print, to the profane gaze of Pākehā readers, too much of sacred oral Māori culture. ${ }^{64}$

The Pākehā gaze has become problematic to Indigenous people. Writing has become a medium where Māori writers portray their lifestyles and cultures, unique as they are from non-Māori. Repercussions about what is depicted have allowed access for criticism in assimilating Māori realities portrayed through fiction.

A more immediate response to perceived Māori realities was seen when the film, Once Were Warriors, released in 1994. Not only was Māori culture criticised nationally but

${ }^{64}$ Romaine, (2004) pp. 31-59 
also internationally, once the film was released overseas. Much like the media in Aotearoa, international media were using the film as an example of "typical" Māori behaviour and behavioural issues. It is also interesting to note that Once Were Warriors has always been referred to as a Māori problem and never as a problem for Aotearoa. Kathy Marks from The Independent reported that:

... it has emerged that the victim's extended family knew of the abuse. But it is Maori custom that people sort out their own problems. Now there are calls for this culture of silence to be broken ... The 1994 film Once Were Warriors helped bring the issue of violence within Maori families to the fore. ${ }^{65}$

To this day, articles featured in the media still refer to the film when reporting any case of social and family issues of abuse. 'Once Were Warriors has been used by both media and leading political figures to refer to a range of issues, including domestic violence, dysfunctional families, and gangs in New Zealand. ${ }^{66}$ Indeed, Once Were Warriors has become such a phenomenon there has even been books written about it such as Once Were Warriors: The Aftermath. The Controversy of OWW in Aotearoa New Zealand by Emiel Martens and Educating Jake: pathways to empowerment by Andrew Eruera Vercoe. ${ }^{67}$ Privately, Māori viewers could express their own opinion about the movie amongst the company of other Māori. But having theories written externally about Māori behaviour takes away any Māori voice or contribution to the discussion.

If one film can raise this much speculation about Māori people then it is understandable that Māori/Indigenous audiences may be reluctant to see or read material about their lifestyle and culture that has been exposed by a writer through a publication. This sort of

\footnotetext{
${ }^{65}$ Kathy Marks, 'Child abuse claims raise queries about Maori culture' in The Independent London: Jul 31, 2007.

${ }^{66}$ Morten Kjeldseth Pettersen, 'Once Were Warriors: The Aftermath' in Pacific Affairs 81:3 pp. 497-8

${ }^{67}$ Andrew Eruera Vercoe Educating Jake: pathways to empowerment (Auckland: Harper Collins, 1998)
} 
generalisation and stereotyping of Indigenous people is not uncommon. American Indian film maker, Shawna Begay, ${ }^{68}$ described at the 2009 Native American Literary Symposium how older Navajo people did not like particular scripts that she had assisted in producing because they saw the scripts as depicting Navajo people in a negative light, even though it was an opportunity for the script writer to express her own life experience. Although her script may have portrayed some problematic situations, it was an opportunity for other Navajo people to make a connection through Begay's stories and feel they were not alone if they had experienced something similar. It encouraged Navajo to be a part of the discussion instead of the being the focus of the problem.

Taking into consideration that some Māori readers may feel uneasy because their lifestyle or culture is open to non-Māori judgements, the question that arises is; how can the practice of the 'insider's view' make a difference to Māori readers? Popular fiction genres like science fiction, pop-romance (chick-lit), crime and murder mysteries written by Māori writers are not widely available. Māori fiction still maintains many themes involving mythology, spirituality, and social realism. Māori writers are using more idiosyncratic language and humour to reflect Māori culture and humour that is readily understood in text. An example of this was my experience presenting a paper at the 2009 Native American Literary Symposium ${ }^{69}$ and read a short exert from 'Pale Flower' (pp. 130-131) and wanted to end on a light note, I read aloud:

'I don't know that we'll be eating what you like,' she said anxiously to me.

'Do you eat pork?'

'Yeah we have pork bones and watercress all the time at home,' I said.

\footnotetext{
${ }^{68}$ Shawna Begay presenting a plenary session about Institute of American Indian Arts New Media Arts Program at the Native American Literary Symposium, Albuquerque, NM. 27 February 2009

${ }^{69}$ Charlie Holland, 'Will Māori Literary Nationalism work in Aotearoa' (oral presentation) at the Native American Literary Symposium, Albuquerque, NM. 28 February 2009
} 
'Oh,' she said. 'This is roasted, with crackling and potatoes.'

'No problem,' I said bravely. 'Sometimes we have wild pork down at the pā.'

'I think you may find that this tastes slightly different,' she said. 'But perhaps you might like it.' It came with gravy, and it was very nice. I had two helpings. I had to, because there was no bread with dinner.

The significance of this piece was having to eat twice as much dinner because of the lack of bread. Growing up, bread was a cheap and popular food for Māori. At any hakari, parāoa rewana (bread) or parāoa hinu (fry bread) or bread brought in bags was generally always served. Māori eating habits are gradually changing for healthier options, but we still associated bread with most meals. In hindsight I realised that my audience's food and eating behaviour were completely different to mine and the 'inside' joke was missed.

For any reader there will always be a commonality the reader shares with the text, whether it is through gender, ethnicity, age, culture, education, or experience. The more Māori readers are able to recognise Māori literature as their own, the more the 'insider's view' will be of affect. Another sort of reader and one more relevant to me is the critic. For the critic or researcher, Māori literary nationalism is not an approach that means to over-ride other literary practices but instead offers a way of drawing particular ideas and concepts that highlight distinctive attributes of Māori literature. There are, however, some restrictions to how this approach can be utilised. First and foremost is the prerequisite that ideally a Māori critic should conduct the research. This segment aims to take in how the aspect of an 'insider's view' is a fundamental position in which the practice can be conveyed. It will also demonstrate how more commonly perceived terminology used through Western standards would be altered to cater to the Māori critic and how a shift to the researcher's audience becomes more targeted. 
In terms of looking at Tawhai's short fiction using the 'insider's view', it would be ideal if certain qualities that gave them the edge of being an 'insider'. Commonalities that qualify many critics to critique Tawhai's work will only have limited scope if the critic is non-Māori. Although a lot of ground can be covered using conventional literary methodologies, I believe that only Māori critics can employ an 'insider's view' as a foundation for a more constructed practice of Maori literary nationalism — as I will go on to explain. A Māori critic presupposes that they acknowledge and identify as a Māori person and can bring a different perspective and interpretation to a Māori text than a nonMāori and 'although there may be commonalities, they still do not entirely account for the experiences of indigenous peoples. ${ }^{70}$ Before we can move on to the process of transferring the concept of the 'insider's view' to the practice of Māori literary nationalism, we must first determine who is the insider, why is the 'insider's view' is valid to the critic and how is the 'insider's view' relevant to established contemporary literary practices. However, defining who is eligible to be a Māori critic can be problematic and may unintentionally offend some critics.

The most obvious answer to who can be a Māori critic is a person of Māori descent. This concept is easier said than done as the definition or recognition of a Māori person does not fall into any distinct category. Since this study is being adapted from a practice developed from American Indian literary nationalism, I will compare the opinion of what categorises American Indians in America to that of Māori in Aotearoa. In the United States of America there is a legal constitution that measures to what degree a American Indian is by the legal registration of 'blood quantum'. The term, 'blood quantum' is

${ }^{70}$ Smith, (1999) p. 35 
legislation that attempts to calculate by what degree you are entitled to be recognised by a native tribe in America through biological linage. The legal process of identifying as an American Indian is quite complex compared to identifying as Māori. For Māori there is no legal process or legislation besides perhaps one's name on the national electoral roles, legal deeds or on Māori trust documents.

In Aotearoa, Māori people are acknowledged as having whakapapa. Whakapapa is a hereditary genealogy and unlike the American Indians, Māori people can legally identify or be affiliated with more than one iwi. However, there are cases where people have been raised as Māori whether it is through legal adoption or whāngai and are not genealogically Māori. There is still remains much debate as to whether biologically nonMāori people can be considered Māori if they have no genealogical affiliation but were raised as Māori. Legally they are not recognised but if they share the same values and belief systems there is little to distinguish them apart. This form of association to a family or iwi is known as whāngai, loosely translated as adopted, fostered or shared. This also goes the same for those Māori who do not physically share the physical traits common to Maori people, most notably the various shades of brown skin, or those Māori who were brought up and lived in a non-Māori environment. If the critic can identify as Māori, than they can also be regarded as a Māori critic. The role of the critic or researcher imposes a perception gathered from the text and as Doris Sommer points out in her paper, Resistant

\section{Texts and Incompetent Readers;}

Critics tend to treat a text as a command performance, even as a pretext for our won command performances. Ever since interpretation freed itself from its origins in pious exegesis, which could remain open to wonder and awe, professional readers 
have tended to take the responsibility, and the credit, for understanding art better than the artist. $^{71}$

There are many reasons why a critic would like to look at any text. I am proposing that we consider how the text affects the critic if they see themselves being socially represented or reflected amongst the society where they reside. In effect the critic's perception changes, no longer able to abide completely as an outsider, regardless of whether the text being read is fictitious.

The work of Tawhai is slowly increasing recognition within scholarly environments. How Tawhai's works are being examined is interesting because of the methodological approaches used to examine her work. Recently an informal public address made by Dr. Jenny Lawn at Auckland University presented a discussion called 'Life under Neoliberalism in Contemporary Maori Literature'. It was an informal seminar that aimed to discuss the following.

Some short stories by contemporary Maori writer Alice Tawhai. Her work dwells on the complexities of race, gender and class in contemporary New Zealand, often in queasy and troubling ways. I [Dr. Jenny Lawn] hope to address her fiction from two different angles. First, what can we learn from her stories about the social changes that have become entrenched in the era of neoliberalism? Second, at a more abstract level: can the category of "Maori literature" itself be regarded as complicit with neoliberal values? The aim is to read Tawhai's work with an appreciation of reading as an inherently political act. ${ }^{72}$

\footnotetext{
${ }^{71}$ Doris Sommer, 'Resistant Texts and Incompetent Readers' in Poetics Today 15:4 (1994) pp. 523-551

72 Jenny Lawn, 'Life under Neoliberalism in Contemporary Maori Literature' (oral presentation) at Auckland University, Aotearoa, 8 April 2009. This information was sent in a personal email to me.
} 
If scholars, researchers and critics are trying to learn from her stories about social change, then they are inherently reading the characters, which are predominately Māori, as contemporary social figures in today's society and seeing a representation of the characters as quoted earlier 'often in queasy and troubling ways'. If these are the concepts that scholars like Dr. Lawn are searching for in contemporary Māori literature, then it is fair to say they may be fallible of missing subtle social behaviours unique to Māori culture — social behaviours overshadowed by prominent confronting and often aggressive or abusive behaviour. Moreover, I am inquiring if Māori researchers or critics are any different in observing cultural conduct if they have primarily been educated with Western ideals. The answer to this came through the Journal of New Zealand Literature (2007) in a symposium based around comparative approaches to Indigenous literary Studies. Dr. Alice Te Punga Somerville discusses in article produced as a result of this symposium:

In Indigenous (Literary) Studies, there is a significant move towards further exploring the idea of Indigenity in order to find new ways to talk about new literatures and new texts, but how we can explore the relationship between 'Māori' and 'Indigenous' without devolving into an integration of definitions that at best deflect the attention away from the texts ... ${ }^{73}$

Symposiums of this nature as well as two symposiums I have attended — the Native American Literary Symposium (New Mexico, United States of America) ${ }^{74}$ and Te Kura Unua Postgraduate Students Conference (Otago, Aotearoa $)^{75}$ - demonstrate that new and different ways of reading Māori text are evolving. Western ideals have produced frameworks of literary nationalism, but they have been nations dominated by one culture

\footnotetext{
${ }^{73}$ Alice Te Punga Somerville, 'The Lingering War Captain: Māori Texts, Indigenous Contexts in Journal of New Zealand Literature, ed. Alex Calder (Waikato: University of Waikato, 2007) p. 22

${ }^{74}$ Native American Literary Symposium held at Isleta Casino and Resort, Albuquerque NM

${ }^{75}$ Te Kura Unua Postgraduate Students Conference held at Otago University, 27-29 August 2008.
} 
and usually those nations have included the works of Indigenous or Native colonised peoples. Claiming Indigenous literature as part their national collection can be seen as another form of colonisation. However, in order for Māori literature to establish itself as independent of mainstream writing, it must use current critical tools and frameworks already recognised within the field.

Although I have discussed the 'insider's view' and how it is, in effect, a perception of the foundation for Māori literary nationalism, this approach is still in the developing stages. In terms of the 'critic' the issue becomes distinguishing who is eligible to be a Māori critic. Further questions need to be asked such as, why would a Māori critic choose an approach like Māori literary Nationalism to critique Tawhai's work and how would the benefits of possessing an 'insider's view' advantage the critic and text. There of course has to be a reason to suggest a new approach in critiquing Māori literature, a reason why the established literary methodologies or approaches are no long adequate or extensive enough to cover certain criteria of Tawhai's work.

More often than not, Māori literature has primarily been studied and researched using established methodologies to deconstruct, explore or investigate a text. Depending on the aim of the research, most literary theories are adequate to use as a practice. However, when the critic, writer, and the text all share an exclusive commonality, there is an opportunity to delve into an analytical territory that privileges a particular insight. In a different medium from written text, an article by Pacific Scholar Selina Tusitala Marsh, who is of Pacific Island descent, discusses a short Pacific film called, The Land 
has Eyes: Pear ta ma 'on maf. ${ }^{76}$ In this article she raises the point that as a Pacific critic of Pacific literature that the 'insider view' points play against those familiar postcolonial spectres of authenticity ... and cultural essentialism. The film was the 'first written and directed by a Rotuman, about Rotuma, set in Rotuma, with Rotuma-based Rotumans speaking the Rotuman language,' and it was a massive achievement, a progressive action towards what Tusitala Marsh signifies as a 'first voicing' for Fiji. Yet, in one critical review the film is objectified at a colonial standard when one non-Pacific critic commented that one of the characters, Taito 'always manages to appear as if she has just stepped out of a Gauguin canvas. ${ }^{, 77}$ The moment that Aleksandra S Stankovic made that comment, the film and the people featured in the film were reduced to no more than an exotic medium for the colonial gaze. In aligning a Pacific perception of the film with that of a constructed fantasy, Stankovic demonstrated a lack of understanding of the Fijian culture.

In effect, the reviewer had to draw on his own level of understanding by comparing the imagery in the film to the paintings and then made the assumption that Fijian and Tahitian people were practically the same, possibly because they both reside in the Pacific. This again is shown in the film Ten Canoes,${ }^{78}$ an Australian Aboriginal film that cast only Aborigine people that spoke their own language. A reviewer's comment was posted on a website saying, 'Perhaps this film can serve as a reminder for the naysayers

\footnotetext{
${ }^{76}$ Selina Tusitala Marsh, 'The Land has Eyes: Pear ta ma 'on maf' Contemporary Pacific (2007) 19:1. pp 306-09

${ }^{77}$ Aleksandra S Stankovic, Harvard Crimson, 24 Feb 2005, www.thecrimson.com/article.aspx?ref=505983 cited in Selina Tusitala Marsh, 'The Land has Eyes: Pear ta ma 'on maf' Contemporary Pacific (2007) 19:1. pp 306-09

${ }^{78}$ Ten Canoes, Dir. Rolf de Heer, Palace Films, June 2006
} 
that there is much of sustenance and worth in indigenous culture. ${ }^{, 79}$ It is almost guaranteed that it would not be an Indigenous culture that thought it was not of 'substance and worth.' In the two comments made about The Land has Eyes and Ten Canoes the 'otherness' of each Indigenous culture is not their own and ignorance of others is still prevalent. What makes these scenarios a little unsettling is these reviews are read by mainstream viewers, creating inaccurate representations of Indigenous peoples. Perhaps having an Indigenous artistic nationalism, like Māori literary nationalism, would give reviewers and critics a more informed perspective on cultural matters.

In terms of criticism of Tawhai's work, scholarly or otherwise, none has been published to my knowledge. The only form of criticism that comes close to looking intently at Tawhai's work is a handful of literary reviews published through national magazines or on the Internet. On one hand it is unfortunate that her work has not been studied more closely, but on the other hand it is beneficial that this research is able to look at her work using a new approach. Critiquing literary material often runs into similar issues that a reader has with literary text, in that, literary construction is often determined through literary practices that cater to western ideals. Material that is produced by Indigenous writers is often seen as text that falls under the category of 'other'.

The concept of 'otherness' has become slightly dated in academic vocabulary, even though the meaning is still present when using substituted terminology like 'ethnic' or ‘ethno', Indigenous or Native. Tuhiwai Smith states how Edward Said's reference to 'Western discourse about the Other which is supported by 'institutions, vocabulary,

${ }^{79}$ Online quote, URL: http://www.creativespirits.info/resources/movies/tencanoes.html accessed on 30 March 2009 
scholarship, imagery, doctrines, even colonial bureaucracies and colonial styles. ${ }^{80}$ Tuhiwai Smith later goes on to contest this suggestion by stipulating 'the Other has been constituted with a name, a face, a particular identity, namely indigenous people. ${ }^{81}$ Admittedly the shift in terminology does empower Indigenous people and the researcher with a little more recognition, but the terminology is still designed to distinguish it from a Western standard. By placing a distinction between people, as Tuhiwai Smith has, and by shifting the terminology from 'Other' to 'Indigenous', allows an ownership over the label 'Indigenous'. By owning the reference such as Indigenous there should be no terminology used at all for researchers using terms like 'ours, 'we' and 'us'.

In a paper by the non-indigenous anthropology researcher, Evard Hviding, he notes that affiliating the prefix of 'ethno' to any sort of literary or scholarly studies politically and socially changes the history and critical approach. For example, Hviding looked at the studies conducted in the Pacific from an anthropological view point and noted how the different veins of proposed research subjects exclusive to the Islands in the Pacific like 'ethno medicine, ethno biology, ethno botany ... but also ethno mathematics, ethno astronomy and many other ethno-versions of western sciences. ${ }^{, 82}$ With the addition of 'ethno' on to any discipline, it separates it from what is the norm and in a sense, places anything 'ethno' in a hierarchical context. Later in the paper Hviding briefly notes the one significant aspect that is crucial to ethno point-of-view and that is 'Oceania's peoples not only have their own histories but their own sciences. ${ }^{83}$ He goes on to describe how at the University of the South Pacific an editorial preface of conference proceedings 'is free

\footnotetext{
${ }^{80}$ Smith, (1999) p. 2

${ }^{81}$ Smith, (1999) p. 3

${ }^{82}$ Edvard Hviding, 'Between knowledges: Pacific studies and academic disciplines' in Contemporary Pacific (2003) 15:1, pp. 43-74

${ }^{83}$ Hviding, (2003), pp. 43-74
} 
from of any 'ethno' prefixes.' The paper written as a result of the conference was written for the people of the Pacific by Pacific scientists. Hviding continues to comment about the research in his article conducted by the Pacific scientists as "them," acknowledging their practices and the conference as something that he, as a westerner, cannot be included in.

This said, the terminology used when referring to Māori text by Māori critics should incorporate affiliated commonalities. Māori literary nationalism would enable Māori critics and researchers to approach Māori literature with an approach of 'we', 'I', or 'us' so that it prescribed to a Māori audience rather than continuing to fall under the Western terminology of the universal 'we', 'I', or 'us' that Māori clearly do not belong. Once text is published it becomes material open to anyone but the use of pronouns will distinguish the 'insider's view' from the outsider's.

The need for any new approach to literary criticism comes as a result of evolving social, political, theoretical or cultural movements. Māori literature has always remained as a branch or category of Aotearoa literature, not through the contents of the text, but who wrote the text. As the numbers of works by Māori writers have increased since the perceived Māori Renaissance, so too has the recognition of the style unique to Māori text. For 40 years, Romaine ${ }^{84}$ argued, a 'new vision that challenges traditional constructs of that country's literature and history as articulated primarily by Pākehā (white) male authors and historians.' Romaine was speaking primarily about Ihimaera's novel The Matriarch but the gist of her sentiments are applicable to other contemporary Māori literature as well. Romaine goes on to explain how:

${ }^{84}$ Romaine, (2004) pp. 31-59 
In novels of the 1970s and 1980s, however, literary critic Mark Williams detected a "deep-seated unease" about the country's cultural situation. He claimed that at no time since the 1930s has fiction in New Zealand been so directly involved with crucial and unresolved questions of national self-definition and evaluation as in the late 1980s. The flourishing of Maori artistic, cultural, and political expression that began in the 1970s has since become known as the Maori Renaissance.

During this time a significant body of fiction written in English by Maori novelists such as Patricia Grace, Keri Hulme, and Witi Ihimaera began to emerge. The appearance of these works heralded a significant shift in New Zealand's literary tradition, from its Eurocentric foundations to a postcolonial perspective that privileges the "insider" or indigenous point of view (see, eg, Grace 1978, in which she argued for a national literature in English that includes the Maori point of view). This transformation is part of a much wider movement throughout the Pacific and beyond. ${ }^{85}$

The Māori point of view has to be advocated not just through the literature, but also through the approach. Although Williams mentions that the shift in New Zealand's (Aotearoa) literary tradition has moved away from a Eurocentric foundation to a more postcolonial perspective, I believe that an approach like Māori literary nationalism can shift even further to allow a perspective that disassociates itself from most Western methodological constructs.

\section{Writer}

Alice Tawhai writes under a pseudonym and her publishers, Huia Publishers Limited, respect that privacy. Although she doesn't allow face-to-face interviews, she has

${ }^{85}$ Romaine, (2004) pp. 31-59 
conducted telephone interviews. What is interesting about a writer keeping her identity hidden is that the public cannot make judgments about her writing based on her personality or personal history. This aspect of using a pseudonym can also raise other issues with regard to identifying Tawhai as a Māori writer. What became unnerving for me as a researcher was the notion that Alice Tawhai may not be Māori. If this is true, than my theory of Māori literary nationalism becomes jeopardised. What I also find unusual is her choice of name for a pseudonym.

Typically in Māori culture, one's name is part of their identity and how they fit within particular communities. Often when I tell people I am researching the writer Alice Tawhai they immediately start trying to make connections with her. As in one's mihimihi, one's name establishes links with other people who may be present. 'It is important for Māori to know and to share their whakapapa — to know one's whakapapa is to know one's identity. ${ }^{86}$ Choosing a name that is not your own could potentially credit or discredit the whanau's name. The only reassurance I have that Tawhai is in fact of Māori descent is from her publishers, Huia Ltd who pride themselves on having a Māori or Pacific focus and Brian Bargh (Publishing Manager) has confirmed her Māori heritage. Huia Publishers have for 'over 15 years ... committed to producing quality books, describing the diverse range of Māori perspectives — telling stories that no one else is telling, saying things that are not being said. ${ }^{87}$ The Huia Ltd website has a blog about Alice Tawhai, which states she is fluent in both the Māori and English languages. This is seen throughout her narrative and her use and comprehension of Māori words. Her tribal affiliations to Tainui and Ngā Puhi are noted in a brief biography, published

\footnotetext{
86 'Mihimihi', Korero Māori, [online] URL:

http://www.korero.maori.nz/forlearners/protocols/mihimihi.html accessed 21 April 2009

87 'About Us', Huia Publishers [online] URL: http://www.huia.co.nz/about-us/ accessed 21 April 2009
} 
when she was announced as a finalist in the 2008 Montana Book Awards on the New Zealand Booksellers website. ${ }^{88}$

Her audience for the large part is herself. She admits in an interview with Philippa Jamieson from the New Zealand Listener that she likes:

... to write for people like me, who have lives like me," says Tawhai. "There are different layers of where people are at in communities. The people up top have got all the voice. They're so busy looking straight ahead at each other that they don't look - down might be the wrong word - but they don't look down. They think that there's part of their layer that's gone bad ... When I was young, it was like, 'Is this just me in a bad place, or are lots of people like this?' If I'd been able to read stories [about people] like me and people I knew, I think that would have been helpful. It's partly why I don't use big words much - I want my writing to be accessible. ${ }^{89}$

However, there are clues within the text in which the reader is able to connect with the writer. There are moments of nostalgia more prominent for those Māori who grew up during the late 70 s and 80 s. Clues given throughout her stories date back to those eras and stated that everything:

$\ldots$ in the stories is drawn from what she knows, from her own life experience she never does research. Yet, like a lot of other fiction, to call it auto-biographical would be misleading. It's more like a lot of photos of her life cut up small and rearranged, so the overall effect is unrecognisable. ${ }^{90}$

\footnotetext{
${ }^{88} 2008$ Fiction Finalist: Montana NZ Book Awards [online] URL: http://www.booksellers.co.nz/mba_fin/fic_08_3.htm accessed March 2009

${ }^{89}$ Jamieson, (2008)

${ }^{90}$ Jamieson, (2008)
} 
Although Tawhai's own life and personality may be "unrecognisable," there are some pragmatic similarities featured in her work that many Māori may have experienced. Tawhai aligns her writing with experience and it is that quality of realism portrayed throughout her writing that gives her work an air of authenticity.

Tawhai notes how she is 'also very interested in what colours and combinations of colours things are; places, words, times and people, and in what lights those colours up. ${ }^{91}$ Her way of perceiving and describing things within her writing has become a creative feature in her work and readily associated with her. Tawhai is a visual person and in one particular interview, interviewer David Larsen stated, 'images come first, and she can tell you what colours she associates with it' and goes on to quote Tawhai saying 'I can see all those colours, and I can see the way those words are arranged.' 92 Although she doesn't believe she has colour-graphemic synesthesia - a neurological condition that allows one to perceive numbers or words in colours — she does say that she thinks her brain may be a "bit unusual."93 The images she creates in her fiction introduce the reader into a colourful imagination. Colours are often associated with Māori artefacts or lifestyle. By linking the imagery with Māori artefacts and lifestyles, Tawhai gives some indication as to who she thinks her audience is. It could be argued that the nationality or ethnicity of the writer is irrelevant and it is the text that is the most important aspect. By using the "insider's view" or potentially Māori literary nationalism, the text written by a Māori writer is also valued. These theories are grounded in cultural commonalities that are shared between the writer, text, and reader.

\footnotetext{
91 'Alice Tawhai' Huia Publishers [online] URL: http://www.huia.co.nz/about/alice-tawhai/ accessed 21 April 2009

${ }_{92}$ David Larsen, 'Alice in the Looking Glass' in Canvas Magazine 2008

${ }^{93}$ David Larsen, 'Alice in the Looking Glass' in Canvas Magazine 2008
} 


\section{Text}

While looking at Tawhai's story 'Pale Flower' I will demonstrate the advantage of exploring the aesthetics and social realism featured in her narrative using an "insider's view". The aesthetics are formed largely through Tawhai's extensive use of colours and often through her use of metaphors and analogies. Tawhai's narratives also demonstrate a sense of beauty in things that often are first thought to be ugly, either physically or psychologically. The contrasts in beauty and ugliness lead the reader to question their idea of first impressions. In alliance with Sommer, this particular story stresses aspects of Māori culture that are more compelling to Māori readers than they might be to nonMāori:

... the rhetoric of selective, socially differentiated understanding ... it is not what 'insiders,' as opposed to 'outsiders,' can know; it is how those positions are being constructed as incommensurate or conflictive. And professional readers, who may share enough social space with a writer to claim privileged understanding and explanatory powers, may miss, or hastily fill in, the constitutive gaps these texts would demarcate..$^{94}$

The story is set in a town that was politically involved in a lot of conflict, demonstrational activity, and land development. In this particular story, the narrator tends to create double meanings of the township's characteristics, the history of Ngaruawahia and of the people in her life. These double meanings are stated as observations made by the narrator or as implications made through norms the narrator claims are everyday. The first line gives the reader a false sense of beauty, 'Sal had a love poem tattooed on to the back of his hand. The words were like greenstone ...', which is quickly diminished

${ }^{94}$ Sommer, (1994) pp. 524-525 
by adding that some 'of the letters had gotten infected.' As quickly as she disparages any image with beauty, she finds beauty once again in the 'infection' by describing it as a 'pale scar'. This movement from beauty to ugliness and then beauty within the ugliness is something often seen throughout Tawhai's fiction. For every situation in 'Pale Flower' the narrator will see or discover something of worth.

The 'pale' used to describe Sal's scars is shown again when she describes a new love interest that enters her life. He is almost the opposite of her current partner, Sal, in that the new man is someone who has a steady job, comes from the Western ideal of a nuclear family, and does not physically abuse her. The new man or 'other one' as she describes him, is Pākehā and never mentions his name but calls him Pale Flower. Again the movement of aesthetic beauty is continued from the pale scar to the Pale Flower, the narrator associates the word flower to the flowering of a bruise that Sal gives to her after a beating (p. 131). The connection between each man in different circumstance builds a complexity around the situation, which is then reflected in a larger picture of the environment where the narrator resides.

From the beginning of the story, Tawhai creates a protective enclosure around the narrator but this enclosure can be seen as being damaged by colonial influences. She mentions how something as precious as a mere kept by her father reminds her of colours seen in the 'distant bush of the Hakarimata Hills, seen through a thin, white Waikato River fog' (p. 123). The mentioning of the Hakarimata Range and the Waikato River is something could be interpreted as perhaps a part of the narrator's mihimihi. However, both the mere and the Hakarimata Range protect the maunga of the area, Taupiri, and are perceived as being aesthetically beautiful to look at from a distance, but if the reader is to 
'look hard,' as instructed by the narrator, one could see the scratching made by people. The Hakarimata Range has been made into a reserve after logging, fires and the introduction of possums, pigs, goats and rodents damaged a lot of the land. From a distance, the Range is beautiful and only now starting to slowly recover from colonial impact. The scratching of the mere is likened to the constant scratching of the range made by the massive coal productions that occur to the north and west of the range. ${ }^{95}$ As with a lot of aspects of this story and the narrator, images change depending on how close or how far away you stand.

Colonial influences also appear in a picture of a Waikato Chief painted and screwed onto signs at the edges of town. The image of the Chief is likened to a Charles Goldie painting. There is much debate around Goldie's paintings in that a lot of Māori regarded the portraits as taonga because they were images of their ancestors. However, Goldie believed that Māori were a dying race or would eventually be assimilated by the colonisers. His portraits were sentimental and romantic and his subjects were positioned in a setting that did not truly represent a lifestyle Māori were living at the time. ${ }^{96}$ So while Goldie's paintings were aesthetically pleasing to some, his paintings also represented a false sense of existence to others.

Tawhai often creates a scenic world around her characters. For many of her characters there is nothing else that exists outside the narrator's city limits. The narrator in Pale Flower describes her town of Ngaruawahia as a place that has shops being 'propped up with wrought iron poles' (p. 123) with a big media advertisement and 'all the cigarette

\footnotetext{
${ }^{95}$ Hakarimata Scenic Reserve, Department of Conservation [online] URL: http://www.doc.govt.nz/parksand-recreation/places-to-visit/waikato/waikato-area/hakarimata-scenic-reserve/ accessed on 13 April 2009 ${ }^{96}$ Charles Frederick Goldie (1870-1947), Tai Awatea | Knowledge Net [online] URL: http://tpo.tepapa.govt.nz/ViewTopicExhibitDetail.asp?TopicFileID=0x000a3dd1 accessed 14 April 2009
} 
butts on the ground where [she] sat' (p. 124). The setting is neither good nor bad, that's just how it is, as if the narrator has no concept of anything comparable. The extent of her exotic adventures came in the form of collecting names of Chinese takeaway stores seen whenever she travelled on the train to the city. The image of cigarette butts scattered on a pavement is contrasted to the 'little starry iron snowflakes' of the overhanging shelters. Both images of the cigarette butts and the flaking paint have replaced or are in poor imitation of the scene that lay before the influences of urbanisation. Her township was also a place of mechanical waste, 'a yard that was meant for rusting carnival rides' (p.125). Tawhai plays on the concept that beauty lies in the eye of the beholder and the reader is only privileged to that insight through the narrator. Images of beauty would otherwise be missed — ' Other people [who] drove through our town without noticing anything' (p. 124). These observations appear only customary to people who reside in Ngaruawahia or similar townships.

Ngaruawahia is a small town but it is a town that has huge political and social significance to Māori. The story is set sometime before the 1990s, indicated by the reference to price of the Woolworths necklace and bracelet set (p. 127). The set cost two dollars ninety nine and in New Zealand one and two cent pieces ceased being made in 1989 and by 1990 were no longer accepted as currency. During the 1980s the Māori land rights movement was still unconfined:

... the Land Rights Movement of the 1970s had a significant impact upon the evolution of Maori political activism in the 1980s. In particular, the high level of 
political intensity that had characterised the struggle provided the conditions from which a young, more militant leadership emerged. ${ }^{97}$

In relation to the land, Ngaruawahia had 1.4 million acres confiscated by the government and as a result tribes located in the area united to protect land and established the Kingitanga movement. ${ }^{98}$ For many young Māori like the character, Sal, there was a lot of frustration and passion behind the political protests and movements occurring during the 1980s. Another part of the issues around Sal's identity as a Māori come through in his objection to his name and the fact Pākehā teachers changed it to suit their own convenience and inability to pronounce his birth name, Herewini. He refers to the name Selwyn as being "plastic" — a superficial coating on a language that suits non-Māori. However, Sal's understands of te reo Māori is not advanced, but to a non-Māori audience he assumes that they would know even less.

The narrator's father is aware of Sal's ignorance saying, 'before you can get like a kaumātua and start sounding off about things' (p. 125) he has to be a man. It's also during this short passage where the reader can see a subtle but distinct indication of generational difference. The narrator's father came from the Baby-boomers generation. 'The boomers grew up in a post-war period of relative affluence and full employment ... and came of age in an era of easy access to tertiary education. ${ }^{99}$ There were jobs available for the Baby-boomers, whereas, the Generation-X that Sal is part of was different and attitudes had changed. Sal's generation would have also been a part of the

\footnotetext{
97 Te Ahu, 'The Evolution of Contemporary Māori Protest', Maorinews.com [online] URL: http://maorinews.com/writings/papers/other/protest.html accessed 14 April 2009

${ }^{98}$ Potential Communities - Ngaruawahia, Department of Corrections: Ara Poutana Aotearoa, [online] URL: http://www.corrections.govt.nz/recruitment/new-facilities-recruitment-campaign/spring-hillcorrections-facility/life-in-waikato-and-neighbouring-south-auckland/5-potential-communitiesngaruawahia.html accessed 14 April 2009

${ }^{99}$ Philip Matthews. 'The X factor', The Press [Christchurch, New Zealand] 15 November 2008, D.1
} 
Generation-X perceived attitudes and as far as 'stereotype goes, [he had] traded the boomers' idealism and passion for cynicism and distrust. ${ }^{100}$ More importantly this era and difference in attitudes is also due to the great Māori urban migration, including the narrator's father who has a typical Māori family that moved to a township where the work was plentiful, only to have industries close or change by time the next generation came along. In the case of Ngaruawahia, it was the freezing works and farming that had changed the employment rates.

There were many Māori who were frustrated and passionate about how to protect the land and for those Māori who occupied it in the story. Their discussions often required many hui. 'I went to a hui last night,' he'd say.'And today we just kicked back and discussed the issues. That meant that he'd been drinking.' The objective for Māori protesting during the 1980 s were focused in their political and strategic philosophies, as far as Maori were concerned they were up against a state of nation that was sometimes seen as being both racist and capitalist ${ }^{101}$. Sal appeared so focused on the Māori activist movement, he lost sight of where his anger was directed, becoming angry at the narrator for not having the same level of understanding in his purpose.

Sal came home late and started picking on me. Māori this and Māori that again. 'Have you ever heard of Potatau Te Wherowhero?' he wanted to know. 'Yes,' I told him. 'What do you know about him?' he asked. 'Nothing, really,' I said. There was no right thing to say. 'Nothing really? Nothing really? What good's that to Te reo Māori?' he demanded (pp. 129-130).

\footnotetext{
${ }^{100}$ Matthews. (2008)

${ }^{101}$ Te Ahu, (2009)
} 
Later when Sal found out the narrator was seeing another man, he appeared more upset that his girlfriend had started seeing a Pākehā rather than the fact that she had been unfaithful in their relationship. Sal reacted as though it was a personal insult to him; he saw 'Te Pākehā' (p. 128) as a representation of an entire oppressing colonial population that Māori were trying so hard to get rid of. Sal makes it clear to the narrator that Pākehā were not just a different culture, but they were people who did not want to understand Māori, their belief systems or values. Although Sal may have appeared angry the narrator had betrayed him, he also felt the need to warn her about the kind of people she was potentially getting involved with and declared, 'He doesn't know anything about us!' (p. 128). This declaration could also refer to the history Sal and the narrator shared, which excluded Pale Flower.

Sal saw that greater implications were attached to Pale Flower; while the narrator became fascinated by Pale Flower's physicality. Her references to Pale Flower gave the impression he was insubstantial and would never develop into anything sturdy. She likened him to a pale, fat flower (p. 127) with 'soft skin like newly risen dough, puffy' (p. 127). The stark contrast between Sal and Pale Flower becomes even more apparent when she goes to Pale Flower's house for dinner and is treated like an alien in her own town. Pale Flower's mother announced to Pale Flower's father that the narrator was something that has been brought home. When something is 'brought home' it is more likely to be a stray animal or something dragged in by a cat. Pale Flower's mother's inhospitable behaviour does not seem to faze the narrator. Both the mother and the narrator are well aware that their cultures are completely different, but the mother maintains an air of superiority while in her house. If anything, the narrator makes an anxious joke about the lack of bread with dinner, which could also be taken as a subtle 
comment about the mother's incompetency at hosting. Food and all it represents is one feature that signals cultural difference throughout the story. When manuhiri are called on by the tangata whenua, they are invited to have something to eat and/or drink after the powhiri/whaktau and whaikorero have taken place. This is done to break the formality of the occasion or to metaphorically "break break" together. In tikanga Māori, the welcoming protocol is tapu, and by convening over food, the formal procedure becomes noa. Pale Flower's mother did not call the narrator into her home, did not acknowledge her presence, and curtly implied that she would not enjoy the food provided.

Throughout the story the narrator is never known by any name and this allows the reader to feel more of a connection to the character. This tactic comes to a head when the reader is left with an open ending and placed in a position where they have to decide which man the narrator chose to live her life with. From an "insider's view" the reader may want to consider that the narrator is being treated differently, but not necessarily kinder by Pale Flower. The narrator could reason that Sal was being physically abusive, but with Pale Flower, the signs are more subtle. Even though Pale Flower liked to watch other girls dance he did buy the narrator real diamonds. The extravagant gifts of real diamonds are acutely compared to the plastic gifts she would buy her daughter to keep her occupied or seen as "guilt" gifts for "watching the other girls". On the other hand, it could also be that Pale Flower was genuinely a nice person, although he was also person who lacked much of a personality in comparison to Sal.

The first-person narration gives the reader the opportunity to be the narrator and consider what life would be like if she chooses to return to Sal to return to her whānau and more importantly her daughter. She would be returning to the land where her bloodlines lie, 
'the tangi at our pā, and the burial on Taupiri Maunga' (p. 128). She left Sal, not Ngaruawahia. Ngaruawahia is a not a place of great change. If the story was set sometime in the 1980s and one of the things she remembers is a sign that stated 'population 5000', it was left unchanged. It is interesting to note that more than a decade later in 2009 the population is still $5000 .^{102}$ Although the main industries have altered over the years, there remains a sturdy Māori community within the town.

In terms of reading this text with an "insider's view" there are many aspects I believe would have been overlooked, had it been read using other literary frameworks. It is easy to note the blatant amount of domestic violence and problematic drinking evident, but it is harder to understand how Māori must have felt during a time when there was a lack of employment, finances, and social respect in small towns. With gang-life featured in the story, this reinforces the desperate need for a sense of belonging for individuals who were grappling with their identity and ready to pursue various measures to reassert themselves. 'Pale Flower' isn't just a story of morals, it is a snapshot of lifestyle, perceived through various eyes but voiced by one. The technique of leaving the narrator nameless allows the reader enact a first-person narrative — an "insider's view

\footnotetext{
${ }^{102}$ Potential Communities - Ngaruawahia, Department of Corrections: Ara Poutana Aotearoa, [online] URL: http://www.corrections.govt.nz/recruitment/new-facilities-recruitment-campaign/spring-hillcorrections-facility/life-in-waikato-and-neighbouring-south-auckland/5-potential-communitiesngaruawahia.html accessed 14 April 2009
} 


\section{Literary Nationhood and a Festival of Miracles}

In the previous chapter I look at the use of the 'insider's view' in relation to Māori literary nationalism. In this chapter I want to discuss the relevance this perspective of the 'insider's view' has in a colonised country where Western literary theories and frameworks have predominately shaped literary approaches. The question of whether or not Māori literary nationalism should be constructed on the basis of 'identity' or 'difference' shall be examined using stories from the first collection of Alice Tawhai's fiction, Festival of Miracles. There are three main points that I will focus on throughout this chapter; comparative approaches, practical criticism, and some of the limitations of Māori literary nationalism.

In the first instance, I will be comparing Tawhai's work to other contemporary literary works by Māori writers, whilst paying attention to contemporary social and political movements significant to Māori people, and how it can influence literature. For contemporary Māori fiction, practical criticism is a methodology that develops the connection or relationship between the reader and the text. This approach is more about the reader and how they interpret text in relation to their own environment. I will then look at Tawhai's texts that portray other ethnicities and cultures, and look the effects of critiquing a Māori writer (portraying an environment that isn't her own) and whether or not Māori literary nationalism can still be applied to the as an critical approach. This will lead into the last point, which is to look at other literary methodologies such as post colonialism, modernism, feminism and cultural criticism, examining how these 
approaches have been a valued contribution in the development for an approach like Māori literary nationalism.

When Māori writers first started publishing their short fiction, there was a definite element of social realism that featured in the stories. Writers like Witi Ihimaera and Patricia Grace described the settings of Māori communities and people, settings that could easily be recognised as actual locations in Aotearoa. This fiction was a source of information that portrayed a form of social and cultural realism. How then does one look at fiction that involves belief systems that for the most part are 'acceptable' rather than 'explainable'? In Tawhai's story 'The Fairies in the Marae' it tells of the relationship one fairy has with a young woman. The reference to fairies conjures up connotations of folktales and mythology. In Māori culture the notion of fairies or patuparehe as referred to in te reo Māori, is a notion that is not always believed, but is generally respected as a spiritual (for the use of a better word) concept. In Vincent Ward's doco-drama, Rain of the Children (2008) ${ }^{103}$ a woman of the local Tūhoe community describes one of the main characters: a young man who was believed to have the ability to talk to spirits. The woman in the documentary explained that his condition could be perceived from two perspectives, on one hand he could be seen as a man that suffered with metal health issues, but on the other hand he was spiritually aware of the curse laid upon his family. When Ward asked the woman believed in such things as patuparehe, the woman acknowledged their existence and implied that they were 'still present in her garden'.

${ }^{103}$ Vincent Ward, Dir. The Rain of Children, New Zealand Film Commission: Te Tumu Whakaata Taonga. (2008) 
This double perspective is seen in Tawhai's story. The title of her story includes the word 'fairies' yet throughout the story she refers to the fairies as patuparehe. Using English terminology readily opens the story up to a non-Māori audience and provides access for a reader to think about these creatures (fairies) and the context in which the story is set. The implication surrounding the word 'fairies' makes the story almost seem fantastical, but the use of term 'patuparehe' throughout the text implies that there is a wider belief system that perhaps includes scientifically unexplainable occurrences or in literary terms, spiritual-realism. I say spiritual-realism instead of magic-realism because in a Māori ideology, things that cannot be explained scientifically are commonly accepted as occurrences - respected on behalf of those who do believe. Magic-realism is more closely associated with Latin American art forms, a term devised by Franz Roh, which loosely means the acceptance of the supernatural as a part of reality.

This story reflects the ritualistic practices still conducted today. In 2007 Janet Moses died in a Wainuiomata house during what was termed by mainstream media as a 'ritualistic drowning,. ${ }^{104}$ In the Dominion Post it reported, 'Dr Hone Kaa, an archdeacon of the Māori Anglican Church, said he was last involved in a makutu-lifting ceremony 12 years ago, but said they were still commonplace.' In later quotes Dr Kaa says, 'You may have to hold the person down because the spirit may fight within the person to stay, so you need others around you to restrain them. ${ }^{105}$ A similar ritual was depicted at the end of Tawhai's story when the people residing at the marae decided to drive the patuparehe out of the woman through the use of water:

\footnotetext{
104 'Police say woman drowned during exorcism' in 3News Mon, 12 Nov 2007 [online] URL: http://www.3news.co.nz/tabid/423/Default.aspx?ArticleID=39014 accessed 1 May 2009 105 'Mother died in curse ritual' in The Dominion Post, 11 Nov 2007 [online] URL: http://www.stuff.co.nz/dominion-post/28258 accessed 11 May 2009
} 
Eventually, they drove him out ... He shot out through the woman's ear, moaning in agony, and bobbed to the surface. They dragged her from the river. She was not breathing, but they drained the water from her, and breathed karakia into her mouth ... But something in her mind was missing (p. 21).

The mental health issues and spiritual practices are both referred to in, actual and fictional, cases. Through the mainstream media cases pertaining to the nature of removing a makutu or a patuparehe from a person are seen as 'Māori issues' within mainstream society. For the most part Māori people acknowledge that these practices have or still occur. However, understandably Māori are less compliant to discuss the nature of these belief systems if they are to be exploited and used for media purposes to portray the Māori population as being dysfunctional.

In keeping with the subject of Māori spirituality, the story also explores the mindset of a writer and a sense of nationhood. In 'The Fairies in the Marae' the journey of the patuparehe up the Whanganui River alerts the reader to many of the cultural attributes that belong to the river's history. It speaks about a part of the river where 'a poet with only one true soul mate had loved many women on a dusty mattress' (p. 15). An obvious connection here would be to the poet James K Baxter and his life at Jerusalem. It describes a community that was once 'full of life', but now remains 'an echo of a memory' (p. 15). This story in particular delves into the life of an artist. As the artist, Baxter once described each of his poems as 'part of a large subconscious corpus of personal myth, like an island above the sea, but joined underwater to other islands', and elsewhere commented that what "happens is either meaningless to me, or else it is 
mythology'."106 Baxter's constant reference to the subconscious and mythology is seen through a lot of his works and in the late 1960s he started a commune life along the Whanganui River in a place he called Jerusalem where he sought 'to form a community structured around key "spiritual aspects of Māori communal life", 107. In regards to Tawhai's story the double perspective of Māori spirituality (the acceptable and the explainable) is implied by the creativity produced by an artist's mind, seeing and hearing things not obvious to others:

See that wood pigeon? He tells me that it is wrong to love another woman.' And her thoughts got mixed up with the thoughts of the patuparehe. To love another woman is a beautiful thing. There can be no wrong in that. (p. 20)

This reference of loving another woman could also be to Jacqueline Sturm, a Māori writer from Taranaki, who eventually became the wife of Baxter. Earlier in the story the narrator refers to the poet's 'soul mate' and then a reference to 'other women'. For the male artist his first love may be art, so the mentioning of a love "between women" may refer to Sturm as a physical woman who also loved the art of writing during a time when writing still remained predominantly a masculine art form.

Sturm was a woman who not only achieved great respect and achievement academically, she also became the first Māori woman to be published in a New Zealand literary anthology. Sturm's stories were thought to embrace the 'era's dominant ethos that New Zealanders were one nation - by avoiding specific reference to Māori., ${ }^{108}$ However, rereading her work using an approach like Māori literary nationalism or 'against the

\footnotetext{
${ }^{106}$ PM, 'Baxter, James, K', New Zealand Book Council [online] URL: http://www.bookcouncil.org.nz/writers/baxterjk.html accessed 1 May 2009 ${ }^{107}$ PM (2009)

108 'Sturm, J C' (2009)
} 
grain' as it was expressed in The Oxford Companion to New Zealand Literature (1998), Strum's stories portray notions of isolation for Māori people in a colonised society.

Tawhai demonstrates, through the journey of the patuparehe, different ideas of nationhood and that of being a part of a nation. Baxter wanted to re-create a nation that held on to Māori spiritual values of what he believed Pākehā urban society had lost. ${ }^{109}$ For Sturm, it may be assumed that her idea of Māori nationhood was not something that could easily fit into Pākehā ideals; failing to become a 'lighter shade of brown'. Tawhai plays with the idea of two cultures, or in the case of the narrative, two species trying to cohabitate as one. The patuparehe in Tawhai's fiction wanted to leave their old society behind, like the ideals Baxter's urban society, because society had pushed them out and so they went in search of the 'old Māori way so that they could carry on being.' (p. 16) Tūhoe country is still one of the few regions in the North Island that have been relatively untouched by industrialism and urbanisation, largely due to its isolated location. Although 'The Fairies in the Marae' may appear like a traditional story, the reference to a post-Baxter, post-WWII period suggests otherwise. The patuparehe and the people of the marae in a way represented two nations who lived along side each other, but could not co-exist when they tried to become one.

The complexity of community can be viewed also within the family/whānau structure. To demonstrate some examples of traditional whānau structures and lifestyles I will be looking at two stories; 'Perfect Things' and 'Dawnie'. These two stories are dissimilar in that they do not hold any in that they do not conform to any traditional family unit of adults and children co-habiting in the same household. Neither of the families are

${ }^{109}$ PM, (2009) 
nuclear, which is realistic in the sense that it is highly unlikely that any two whānau are structured in the same way. Although each of these stories has many different themes running through them I will concentrate on the relationships between characters to try and focus on particular characteristics that make whānau dynamics distinct. In 'Perfect Things' the story is told from the perspective of a small child. The narrator is a girl who likes to collect things that that 'catch her eye,' pretty things. She unconsciously compares herself to unrealistic objects noticing how shop mannequins have skinny stomachs and how perfect a bar of chocolate looks 'no bites taken' (p. 55). Her 'prize' comes when she and her cousins find a dead body in the river. The body is of a Pākehā woman and after initial curiosity; the children begin to play with the body like a toy. The dead woman is likened to a shop mannequin, a Barbie doll, something that doesn't exist in her world, yet this is the image that the girl believes is correct. The girl has issues with her own body image and thinks that she is fat. However, it is from her family the girl is reassured that she is not the abnormal one. Her father calls her 'fatty' in an affectionate way and her mother tries to prove that big is beautiful, "You look, she said, 'at any kapa-haka group. You'll never beat a big woman for the way they sway and dip. Those skinny girls just can't touch it" (p. 56). The lifestyle that the narrator has is 'realistic', and when she is reprimanded by her father to "look away from the dead body", it reminds the reader of how the girl's perception of people and things outside her environment has become distorted. The children display no sign of respect for the body, even if it was foreign matter to them.

In 'Perfect Things' the girl describes food as things that are perfect, but there are also foods that she regards as bad, because she fears that they are fattening, like the wedding cake, chocolate, flounder, and doughboys that her nanny makes for the stew. Food, as 
described in chapter one, is an aspect of Māori culture that represents so much more than nutritional substance. The preparation of food is important to the bonding of family members and this is seen in Tawhai's short story, 'Dawnie'. The annual pie competition sees the whole family getting involved. In this particular gathering there is a mixture of generations, but the story focuses on the eldest child, Dawnie. It's not clear what the character's connections are, but the readers can gather that Uncle Joe and Martha are a couple, possibly Dawnie's parents, and Uncle Joe, Blue and Uncle Mick are other adult relations. The three younger ones are Dawnie herself, Pipi and Eru.

In contrast to the drama that happens in the story, this is one of Tawhai's stories that some element of light humour featuring in the narrative. There is jesting between the men about trying to find the 'ultimate pie filling' and Blue offers to go hunting for a moa. The animosity between Uncle Joe and his archrival, Koro Whaitiri, who has won the Mason Bay Pie Competition the past few years, is concealed when they see each other again and they both act very casual making comments about the weather. Amongst all this competition chaos, other concerning observations are being made by Uncle Mick of Dawnie. Uncle Mick comments to those around him, that he notices Dawnie's body maturing, 'That girl's growing up,' said Uncle Mick ... 'She's busting out of all her clothes' (pp. 134-5). Uncle Mick's comments go unnoticed almost giving him permission to take further advancements towards Dawnie. Dawnie is aware that something is not right; giving the impression that she doesn't quite understand or know why she is feeling so unsure. Her behavior is understandably child-like often whining about things and getting upset easily. 
The tension of the competition grows as everyone heads off to the venue. En route Uncle Mick makes his advances on Dawnie by placing his hand on her leg - no longer regarding her as a child, but a sexual being. Dawnie rejects his touch, but Uncle Mick persists in placing his hand on her leg until Dawnie makes herself 'feel sick' so that she can sit near the car window. Uncle Mick also begins to call Dawnie 'cuz' as a sign of her physical maturity. Uncle Mick may refer to Dawnie as 'cuz', but Dawnie still addresses him as 'Uncle' Mick. Within whānau structures it is not uncommon to call someone a generation older than you and who is close to the family (but not necessarily a blood relation), uncle or aunty as a sign of respect. Equally, these terms of endearment can be seen in other Pacific writing like Célestine Hitiura Vaite's books, Breadfruit, Frangipani and Tiare. The attitudes towards whānau in Vaite's book show a strong similarity to those found in fiction written by Māori writers who also use personal titles such as aunty, cousin and Mamie, given to people in accordance to age rather than biological lineage.

At the pie competition the weather (metaphorically) indicates that something is about to happen, 'Outside, she could see the clouds swelling and turning purpley-black like bruises' (p. 138). Just as the rain begins to fall, Dawnie also begins to menstruate, physically marking her progression into womanhood. The reader is left with an image of Dawnie crying, possibly because she is hormonal, possibly because she knows that things for her are about to change and that men will start to pursue her whether she is ready for it or not. Repercussions of this story can be likened to the movie Once Were Warriors (1995) where the character, Uncle Bully, has similar characteristics to Uncle Mick in Tawhai's story. The story 'Dawnie' shows that the teamwork and efforts for the competition by the whānau ultimately depends on their support for each other in order to gain success. A sense of hope that they will also be there to support Dawnie, if needed, is 
implied. The suggestion that Māori people support one another within the whānau unit has assisted in keeping Māori communities together, has not and is not, always the case. There are alternative structures of whānau that have been formed to meet the needs of other Māori communities, seen in stories such as 'Thicker than Water'.

The Māori people defied early assumptions that they were either going to become extinct when Aotearoa first became colonised; at 'the turn of the 20th century, Māori were reportedly a dying race, ${ }^{110}$ or that they would assimilate with the colonial settlers. 'Disease and land loss had apparently taken their toll on the population with a drop from an estimated 100,000 Māori in 1840 to 45,000 in $1901 .^{, 111}$ The assimilation of Māori people towards a more Pākehā-friendly physicality and culture had not worked, although undoubtedly Māori culture had been affected. For many communities there were feelings of displacement and a sense of wanting to belong, which had developed through other means that were not only based on biological relations. From the 1960 s through to the 1980s, the suggested time period that Tawhai's narratives were set, many Māori were affiliated with gangs, the gangs becoming their whānau which fulfilled their sense of belonging. Displacement also came in the way of urban living. Not in the urban structures of corporate or industrial employment, apartment residences and leisurely pasttimes, but more the communities that formed on the streets. It was the street-life of young Māori who lived contently by avoiding the law, knowing the language and knowing acceptable street conduct. By looking at alternative whānau structures and how they formed a society in which Māori believe they belonged, demonstrates a latent nontraditional lifestyle.

\footnotetext{
110 ‘About Māori: Profile’ cited on FOMA: Federation of Māori Authorities, Me Uru Kahikatea [online] URL: http://www.foma.co.nz/about_maori/profile.htm accessed 3 May 2009

111 ‘About Māori: Profile’ (2009)
} 
In a documentary 'Girls in the Hood' produced by TV3's 60 Minutes, women who were aged in their mid- to late-teens were interviewed about their lifestyle in a 'girl gang'. The documentary's commentator tried to prompt the audience's curiosity by saying, 'Sarah Hall went to meet them and find out why they do it and whether they prefer to be a bit more (pause) well, feminine. ${ }^{112}$ What seemed ridiculous about this particular report on girl gangs was that the whole feature was obviously catered for a predominately nonMāori audience. It is unlikely that the young women involved in the girl gangs had even considered altering their appearance to suit the ideals of mainstream femininity. An underlying message that appeared to continuously over-ride the subject matter was the fact that the girls belonged to a form of whānau within their environment and society.

Tawhai also deals with gang-life and life of Māori living in lower socio-economical situations through her narratives. What I am proposing through the practice of Māori literary nationalism is that Māori readers and critics start looking at text without comparing the situation to non-Māori circumstances or ideals. This would mean to look at the narrative within its own context, much like one would regard the women featured in the girl-gang documentary where the thought of being 'feminine' seems irrelevant to the fact that these women have totally different values and belief systems within their environment. To place Tawhai's stories into a context of non-Māori values and lifestyle is a reflection of social-realism, which would in effect have results that highlighted violence and substance abuse as dominate features, and possibly as the cause and reason behind (perceived) dysfunctional behaviour. When researching into 'Māori gangs' (through academic electronic databases), the only information available was from New

${ }^{112}$ Sarah Orr, 'Girls in the Hood' on 60 Minutes: TV3, April 272009 
Zealand newspaper articles, none of which are marketed toward a Māori audience.

Because this was the only information that was readily available as an academic resource, I disregarded it as reliable and reasonable source material.

The characters in 'Thicker than Water' eventually become associated with gangs as they grow older. The three main characters, Lewis, Huck and the narrator have known each other since they were young children and decide to make a blood pact to solidify their relationship:

Huck spat on a piece of glass to get some of the mould off, and then drew a straight line across all of our wrists with his right hand.

It was like drawing with chalk. A red line of blood sprang to the surface straight away, and it stung like hell. We rubbed our wrists together, and Huck said that blood was thicker than water, and that we would always, always stand by each other. (p. 31)

The act of cutting their wrists can symbolically represent a suicide pact. The cut was a marking of their childhood and in a way a death to their innocence as children. This innocence is seen when the three witness Huck's older sister in a sexual act with her boyfriend. They are more worried about getting caught eating coconut cakes under the bed than what is happening on the bed.

After each of the characters make the pact, the story jumps forward to the future. Although they are all still close, life has changed for them, and Huck has become a prospector for the Mongrel Mob. The average age for most prospectors is generally midto late-teens, much like the women from then girl gangs on the TV3 documentary, so these characters would most probably be in their late teens as well. The bond between the 
central characters is placed in jeopardy when Huck sacrifices the narrator, his girlfriend by this time, as a 'sexual commodity' to the rest of the gang. The sacrifice goes awry when the narrator is yanked out of the car parked outside the pub, by Lewis, who distinguishes her alighted hair and drags her away.

This act is a mark of how Huck severs his ties with the other two characters in order to belong to the 'whānau' of the Mongrel Mob. There are two possibilities about the ending of this story, which sees Lewis being beat up and possibly sexually assaulted in the toilets at the same pub where the narrator was assaulted. It is hard to determine whether the narrator has been asked to persuade Lewis to join her at that particular pub on that particular day, or whether it was a coincidence that some gang members were waiting there. Walking in on Lewis being beaten and left bleeding by the urinal, the narrator is told to walk away if she doesn't want the same thing to happen to her, and so she does. As the narrator leaves she looks down at the bond she too has severed, but walks away from the sacrifice she has made to save herself or possibly the sacrifice she has made to Huck:

So I shut the door behind me, and walked out of there. I kept on walking and walking. And all the time, I was looking down at the finely drawn scar on my left wrist. (p. 35)

What is depicted through these actions is that the narrator had to do what she thought was best in order to save herself, or another way of looking at it, is that she was trying to save face and secure her safety in that community.

For many Māori, like the characters in the story, or even the young women on the TV3 documentary, the life and community that one has been brought up in is the only world 
that one knows. In the story, Huck's status within the Mob progresses, 'Wears a red scarf. Acts like a dickhead ...' (p. 34), which would have meant that the expectations of the narrator would have been to accompany Huck if she was indeed still in a relationship with him. The narrator needed to 'belong' and she had never felt that connection to Lewis because he was never interested in her or any girls that she knew. This could imply that he was homosexual or that he knew that if he got involved with local girls his chances of moving away from his environment would become increasingly difficult as the narrator demonstrated through her own experience. Tawhai renders an environment that depends on belonging to one group or another in order to be accepted.

Living away from the security and hieratical conventions of gangs, Māori also reside on the streets. In the stories 'Festival of Miracles' and 'To Jess' it highlights the themes of isolation within a busy city. Both the narrators in the story have someone close who they regard as family or a loved one, but there is no mention of a large whānau-like group that they depend upon for security. Often their social interactions are conducted at night when the bright lights of the city are lit up and social conformities are more relaxed. 'To Jess,' is a story that salutes that 'metaphoric person,' who has meant something special in one's life, but is no longer around for some reason or another. It is a story about birth or rebirthing after having lost everything. The story starts with the narrator introducing the reader to Sahra. Sahra, who eventually becomes the narrator's 'Jess', is described as being attractive, brazen and assertive. Her confidence gives an impression that Sahra is most likely a sex-worker on Karangahape Road in Auckland:

We went past the brightly lit signs showing cartoons images of reclining women with big tits and tiny waists, flashing in the neon pink manages to look sickly and sexy at the same time. A car slowed down and a man asked if we were looking for 
work ... We tried to get in at a club, but the bouncer wouldn't let us. Too young. Sahra unbuttoned her coat and flashed him, naked except for a lacy black bra and undies. The bouncer laughed. 'That won't get you into this club,' he said, 'but it'll get you into my pants.' (pp. 43-44)

The narrator's compliance to follow and obey Sahra indicates that Sahra is her mentor and for the most part, all that she has. Sahra is portrayed as friend and confident who encourages the narrator.

Each of the girls belongs to an environment that is isolated from a larger Māori community, instead choosing to encompass the different cultures that are also a part of the urban setting. Tawhai also has similar sentiments in 'Festival of Miracles' and after the narrator, Hana, resorts to living in Auckland City, she finds comfort in the different ethnicities within the city culture, 'Auckland smelt of coconut cream and Chinese cabbage. The first job she found was injecting Turkish delight ...' (p. 3). The two girls in 'To Jess' experience an encounter with a Chinese man who tells them of the lunar eclipse that night, describing the occurrence as the 'dragon [that] will make the moon devoured' (p. 43). This reference is used again as the narrator imagines Sahra blowing smoke like a mythical dragon (p. 45) and again when Sahra says that she will devour the narrator 'like a dragon'. The actual act of blowing breath into the narrator's mouth and nose is likened to a birthing and the first breath being blown into a baby's lungs. It is also relevant that this episode happens on Christmas Eve when the birth of Jesus is celebrated. The last image that the reader is left with is the narrator looking at an altar with a statue of the Madonna. There is a stark contrast made between a lifeless Madonna in dark robes to the scantly dressed Sahra, yet both women are worshipped and are seen as saviors to those that worship them. The narrator looks over the city as the sun begins to rise and notes the, 
'empty streets where everyone who had a home had already gone to it' (p. 46) she is still there, and still homeless. But, hope is given when the last words of the story, 'Christmas morning' signifies the birth of a new day after the death of the moon.

For Hana, in 'Festivals of Miracles' it was a matter of escaping everything she knew in an attempt to escape from the memories of losing her baby and everything that she associated with her past. There is a constant play on darkness and light, each bringing its good and bad connotations, and memories. On the night that Hana's baby died, she and her cousins go to the beach to watch an unusual phenomenon of stars falling in the night sky. Later when she moves to the city an incident of falling mirror shards from the ceiling remind her of that starry night. Superstitiously, the smashing of the mirror also represents seven years of bad luck.

There is an English idiom that says that 'the darkest hour is just before dawn,' meaning that there is hope, even in the worst of circumstances. In both 'Festivals of Miracles' and 'To Jess' the narrators sit in the dark and wait and watch the sun rising the next day. They sit in a city full of an artificial glow of city lights waiting for something real to appear. For Hana, she is reminded of the hurt she feels as a childless mother, but is also reminded that she is someone's daughter and takes a moment to remember her mother, imagining her 'in the garden where life grows'. The reader is left with the impressions that like Hana; Hana's mother has also lost her child, not to death, but to grief. Displacement has left the characters from these two stories with feelings of isolation.

We can understand or empathise with the sort of environments that are created through Tawhai's fiction by either relating it to our own experience of that time period or perhaps 
learning through other avenues about how Māori lifestyles and Māori communities were, and still are, in Aotearoa. Although, how Māori see themselves in literature, often depends on what influences are around them at that time. Festival of Miracles was published in 2005 and regardless of when the stories were set; they are read with the knowledge that Māori had to challenge the New Zealand Government as a nation for the Waitangi Tribunal (1975), the introduction of the Māori Party to the New Parliament (2004), Foreshore and Seabed Rights (2004), Urewera Terrorist Raids (2007), Treaty Land Settlements (2009) and most recently the exclusion of Māori seats on the Auckland Council (2009). The publicity around events such as these in mainstream media has never been portrayed favorably to Māori people.

If Māori readers and critics acknowledge that fiction created by non-Māori writers is something of an 'issue of misrepresentation', than the issue of Māori writers writing the 'other' must also be taken into consideration. Does Tawhai have the right to portray a culture that is not her own? And how does a Māori critic address that narrative using an approach like Māori literary nationalism? In Tawhai's, Festival of Miracles, there are at least four obvious stories that do not directly identify the characters as Māori: 'Russian Onions' (Chinese); ‘Imagining Winter' (Lebanese); ‘The Magic Taro’ (Pacific Islands); 'Mr Caprice's World-famous World Fair (Italian); and a few other stories where ethnicity has not being clearly defined.

There have been literary approaches that have led the way to more acute frameworks apart from an approach like that of Māori literary nationalism, which have raised the issue of how accurate literary methodological practices are towards a culture portrayed in literature. In an article called 'Transforming the insider-outsider perspective: Postcolonial 
fiction from the Pacific,' Sandra Tawake ${ }^{113}$ questions who possesses the 'real world island voice? Who is the insider?' She goes on to dissect the nationalities of Māori writers and to some degree doubts the authenticity of their cultural identity, writers such as Patricia Grace, Alan Duff, Witi Ihimaera and Keri Hulme because of the non-Māori influences or affiliations that they each have. However, it is agreed that through such literary frameworks as literary post-colonialism Māori writers have come about to speak from the insider's view and have raised 'modern issues of contested identities, social constructions of reality, and who is empowered to speak for peoples ${ }^{114}$ in Aotearoa. Regardless of what non-Māori influences Māori writers may have, if they have Māori whakapapa and believe that they are Māori then surely it is not the critic's place to argue their heritage. This said, I therefore do not believe that the practice of Māori literary nationalism can be used to study the text of stories that are not told primarily from a culture that is non- Māori. The only admission to the text would be through the writer as a Māori person who may have witnessed or researched the material. To assume another culture's social, political and cultural attributes, would be hypocritical - such as a critical approach to stories like 'Russian Onions', 'Imagining Winter', and 'Mr Caprice's Worldfamous World Fair' using Māori literary nationalism.

The contemporary short fiction in Tawhai's collection, Festival of Miracles, should be read and criticised within its own context, alongside other forms of literature and accounts when applying the practice of Māori literary nationalism. It is too easy and less effective to compare her works to other fiction written by non-Māori writers to demonstrate differences in theme and narrative style. There are literary approaches like

\footnotetext{
${ }^{113}$ Sandra Tawake, 'Transforming the insider-outsider perspective: Postcolonial fiction from the Pacific' in Contemporary Pacific, (2000) 12:1 pp. 155-175

${ }^{114}$ Tawake, (2000) pp. 155-175
} 
postcolonial criticism that does lend the insider's voice to the critic, but often it is by using a comparative technique that it steps away from the insider's view to examine the context. By constantly focusing on the text using an 'insider's view', Māori literary nationalism can focus on the material, thereby making distinctions that are unique to contemporary Māori writing by drawing and comparing the text to itself. There is enough literature produced by Māori writers to deconstruct, analyze and simply enjoy without having to rely on material from non-Māori cultures to practice Māori literary nationalism. 


\section{The Indigenous Nation and Luminous}

Māori literary nationalism is an approach that has developed from the need to explore Māori literature using a framework that caters for readers and critics, particularly those of Māori descent. Short fiction written by Alice Tawhai and other contemporary Māori writers is increasing with work being submitted to national publications and the Pikihuia Awards for Māori Writers biennial short fiction competition hosted by Huia Publishers. This chapter investigates whether Māori literary nationalism can be practised as a singular form of literary approach or whether it has the potential to be a component of a wider context. I would like to think Māori literary nationalism would be regarded in equivalent extent to other Indigenous literary approaches, especially to those nations colonised by Western influences.

Each nation has experienced the process of imperialism and resistance to Western ideology that led Indigenous people to develop a way of thinking incorporating Western principles. Through the colonisation process we have developed a way of expression that envelops the literature with our [Indigenous] storytelling and arts, making it exclusive from non-Indigenous narratives. Basing this notion of Indigenousness on American Indian literary nationalism, I will be selecting particular works from Alice Tawhai's second collection, Luminous to examine and reveal how Tawhai's narratives function on an Indigenous scale and show the relevance of her wording and how it can be produced through an approach such as Māori literary nationalism. 
Through casual discussions with other Māori scholars in Aotearoa and Native scholars at the Native American Literary Symposium held in Albuquerque ${ }^{115}$ there appear to be a recurrence of concerns regarding the approach of Māori literary nationalism and specifically the term "nationalism". Firstly, nationalism is a Western construct with principles and meaning that were never designed to correspond with Indigenous values. This 'raises questions about the concept of nation (or national identity), often defined in terms of common origin, ethnicity, or cultural ties, and while an individual's membership in a nation is often regarded as involuntary, it is sometimes regarded as voluntary., ${ }^{116}$ The concept of unwillingly belonging to a nation is not obvious to Indigenous people in their own nation until the introduction of how they are expected to behave or a questioning of their values and beliefs by outside persuasions.

The conception of who is regarded as a Māori reader or writer or what can be considered as Māori text solicits whether these factors are consciously chosen as to whether or not they belong to a Māori nation. In the first of the stories for this chapter I will be looking at Tawhai's story 'Is This the Promised Land?' 117 where two characters are born of Māori descent, yet their up-bringing and society informs them otherwise. The two characters both feel uncomfortable in their own skin yet are unsure if it is their culture or skin colour that is the mismatched factor, neither of them feeling they belong as Māori or sense nationhood.

\footnotetext{
${ }^{115}$ Native American Literary Symposium: Isleta Resort and Casino. Albuquerque, NM. United States of America. 26-28 February 2009.

${ }^{116}$ Nenad Miscevic, 'Nationalism', The Stanford Encyclopedia of Philosophy (Fall 2008 Edition), Edward N. Zalta (ed.), URL: http://plato.stanford.edu/archives/fall2008/entries/nationalism/ accessed 14 May 2009. ${ }^{117}$ Alice Tawhai, 'Is This the Promised Land' in Luminous (Wellington: Huia Publishers, 2007) pp. $127-$ 133
} 
'Is This the Promised Land?' is a story a young woman called Steph who was born with blond hair and blue eyes but was fathered by a Māori. She is envious of her brother who was born with darker features:

... when the brownness of her father's skin had flowed so easily into her brother? What had blocked her father's colour from passing across her placenta ... leaving her colour gold and blue and fair and unfinished when she emerged? (p. 128) Steph can't comprehend how she was born without recognisable Māori features and feels cheated and incomplete. She dreads knowing that she will eventually grow up to look similar to her non-Māori mother. Besides having fair skin, Steph sees her mother as someone trying to deny her of her Māoriness - cheating her out of a heritage that she feels she has some rights to. The narrative goes on to compare Steph's fairness to Evangel's dark complexion - a young man in her art class. Evangel was born to a nonMāori father and a Māori mother. He also felt he had to deal with issues of being perceptibly Māori in a non-Māori environment. The story continues back and forth between Steph and Evangel, who both want to belong to the culture their skin colour does not portray. This element of displacement leaves both characters feeling the need to express their isolation and frustration through their art.

Featured in this story is renowned spiritual painter Colin McCahon, whose works are often recognised by the bold contrasting colours of black and white with text drawn into the work. In one particular piece, a Christchurch Gallery examines his work entitled 'As there is a constant flow of light we are born into the pure land' and details:

... much of McCahon's painting, this work has a limited tonal range. The symbolic potential of black and white refers to the profound oppositions of life 
and death, good and evil, ignorance and revelation. All these are issues which are fundamental to McCahon's art. ${ }^{118}$

These sorts of polar similarities are also made between Evangel and McCahon - both having religious affiliations and resided in Dunedin. In some degree Tawhai links her work as a writer to other art forms. McCahon was a storyteller through the medium of painting that spoke in metaphors ${ }^{119}$ of constant dark and light. There is regular referral to McCahon's work and the interconnected relationship between Steph, Evangel and society. Both characters are metaphorically living in the grey spaces between the black and white boarders. ${ }^{120}$

There is a strong millenarian quality to McCahon's vision. The landscape of 'splendour, order and peace' is not far removed from Blake's city of God in 'England's green and pleasant land'. Earlier paintings such as The Promised Land, 1948, and Was This the Promised Land, 1962, reflect this quality. It receives its fullest expression to date however in two paintings that pay powerful homage to the millenarian vision of the Māori prophets Te Whiti, Te Kooti and Rua. The Parihaka Triptych, 1972, which the artist presented to the Parihaka people, commemorates Te Whiti, and the large Urewera canvas (which hangs in the Urewera National Park Board building at Waikaremoana) Te Kooti and Rua Kenana. In this smoulderingly beautiful painting McCahon depicts the brooding majesty of the Urewera country and also the inseparable bond between the people

\footnotetext{
${ }^{118}$ Colin McCahon, As there is a constant flow of light we are born into the pure land. (Christchurch: Christchurch Art Gallery Te Puna o Waiwhetu, 1965)

${ }^{119}$ Neil Rowe, 'Notes Towards a McCahon ABC' [online] URL: http://www.artnewzealand.com/Issues 1 to40/mccahon08nr.htm accessed 14 May 2009

${ }^{120}$ Rowe, (2009)
} 
and the land which is the very essence of Māori tanga and which should be the heritage of all New Zealanders. ${ }^{121}$

Tawhai plays on the title to disarm the vigilant titles of McCahon who strongly portrays what he believes to be the values of 'Māoritanga'. The questioning title, 'Is This the Promised Land?' is written as a response to a spiritual artist who was so revered in New Zealand, often associating him with the likes of poet/painter William Blake, a quasiprophet who believed he could change the world through art. ${ }^{122}$ Tawhai defies that theory, revealing that nothing is ever easy or simple when attempting to define a nation or the attributes of nationhood. This story could be seen as a challenge to McCahon's visions but there is one perspective clearly demonstrated about the difference between being Māori and believing you can understand what it is like to be Māori, empathetically. Despite Evangel wanting to pass as Pākehā, his skin colour and features would always portray differently. His longing to be accepted into a culture where he did not conform was always challenged by non-Māori perspectives that cast stereotype assumptions of him. 'He hated when one the lecturers would ask him, in front of the whole class, for the Māori perspective. How would Māori feel about this, Evangel?' 'What would this mean in Māori terms?' And Evangel had to shrug his shoulders ...' (p. 128). This sort of assumption was also seen later in the story when negative stereotype casting was directed at him:

A policeman stopped Evangel as they walked towards the Square. 'What are you doing around here?' he asked him.

${ }^{121}$ Rowe, (2009)

${ }^{122}$ Rowe, (2009) 
'We're here for the carols by candlelight,' said Steph, who had been looking in the shop window. 'Why don't you ask those other people what they're doing here?'

'Sorry, miss,' said the officer. 'I didn't realise that he was with you.'

'It doesn't matter who he's with,' said Steph.

'Just doing my job, making sure no one breaks into these cars,' said the policeman. (p. 130)

This is an example of how a person like Evangel could be seen as an "involuntary member" of a nation. Someone like Steph could never understand what it feels like to be treated and regarded in such a way. Referring to American Indian Literary Nationalism and associating a national group determined by the idea of culture, Weaver views nationalism as a term that 'also includes sovereignty, culture, self-determination, experience, and history, that is central to understanding the relationship between the creative expression of Native American literature and the social and historical realities that such expressions embodies. ${ }^{123}$ By contrasting the two artists, McCahon and Tawhai, only one of the characters out of Steph and Evangel can experience what it is to be Māori, to be treated as Māori and regarded as part of a nation separate from the mainstream.

Undoubtedly there have been many cases of Māori being identified as a non-Māori because their physical features were not "typical" of Māori people. In the story Steph desperately wants to be asked difficult questions about Māori perspective but feels she would never be accepted because of her lack of te reo Māori or that she had never been onto a marae and can barely remember her Māori father. Her longing was to be

${ }^{123}$ Ortiz, (2005) p. xv 
acknowledged as someone of Māori desent. In 2003 there was an incident that challenged and questioned the integrity of people who had never acknowledged their Māori heritage until it presented itself as a personal benefit, when Christian Cullen was selected to play for the Māori All Blacks. This act in itself would not have been so bad if Cullen had not have made the flippant comment about being 1/16 part Māori .

In an article written by Brendan Hokowhitu and Jay Scherer ${ }^{124}$ the issue was explored further, 'The public controversy over the selection issue was further inflamed by Cullen who contemptuously suggested he was eligible for the Māori team because, "You only need a little fingernail, don't you?"125 while sarcastically noting that he would have to learn te reo and the Māori All Blacks' prematch haka., ${ }^{126}$ The "little fingernail" he was referring to is the amount of Māori blood need to be identified as Māori. Having never played for the Māori team previously or publicly identifying himself as Māori, Cullen claimed indigenous status via whakapapa (genealogical connection) to his Ngāi Tahu grandfather. Many New Zealand rugby fans and pundits greeted Cullen's newfound indigenous identity with derision and cynicism. These sort of matters would come into account when asserting a practice that primarily served Māori nationalism, even through literary avenues. It is illogical to think that Māori nationalism can disqualify a person who believes they are Māori if they can trace their whakapapa and, in ways, should never have any parameters. If we were to scrutinise the authenticity of Māori heritage, then we

\footnotetext{
${ }^{124}$ Brendan Hokowhitu \& Jay Scherer, 'The Māori All Blacks and the Decentering of the White Subject: Hyperrace, Sport and the Cultural Logic of Late Capitalism' in Sociology of Sport Journal (2008) 25, pp. 243-262

${ }_{125}$ M Butcher, (2003, August). What is Maori? Who is Pakeha? North \& South, pp. 36-47.

${ }^{126}$ Moorfield, J. (2005). Te aka: Mäori-English, English-Mäori dictionary and index. Auckland: Pearson.
} 
would be one step closer to asserting the act of certifying a "blood quantum"127 - as seen in the United States.

Māori literary nationalism is a mechanism that can beneficially serve Māori literature, as well as placing Māori literature at risk by Māori critics who assert having "a fingernail's worth of Māori." ${ }^{128}$ The main aim of having Māori literary nationalism is to allow space for discussion about certain aspects of Māori literature and to explore it from a different angle. This could very well include topics about how "Māori" does one have to be before they can be considered a Māori reader or writer. Contributing critic and scholar to American Indian Literary Nationalism Robert Warrior stated how he believed the Native perspective would work for facets of all realities, 'For me, privileging Native voices was not a matter of infusing Native perspective with infallible access to truth, but a recognition of the need to be methodologically self-conscious in attending to perspectives that had been ignored, debased, discounted, and marginalized. ${ }^{129}$ This is where a Māori critic has the opportunity to discuss matters that have been "ignored, debased, discounted, and marginalized" within a safe space. In Tawhai's story 'Dark Horse' the material is raw and controversial and by exploring the text and contrasting and comparing it to dominant Western or non-Māori literatures; I hope to articulate a unique perception and bring certain issues to the forefront.

In Tawhai's story 'Dark Horse' the contemporary Māori distinctions are more obvious. 'Dark Horse' tells another side of gang-life for Māori people in Aotearoa. Much like the stories 'Thicker than Water' and 'Pale Flower', 'Dark Horse' is told from a teenager's

${ }^{127}$ Gregg L. Lewis, 'Enrollment Procedures and Recourse' University of Oklahoma [online] URL: http://thorpe.ou.edu/OILS/enroll.html accessed 30 September 2009

${ }^{128}$ Hokowhitu \& Scherer, (2008) pp. 243-262

${ }^{129}$ Warrior, (2005) p. 195 
perspective, a teenager that is associated to a gang through his friends. It is implied that the narrator was raised directly within a gang environment. Interestingly, Tawhai has featured core Māori gangs that are prominent in Aotearoa in both her books. In 'Thicker than Water' it was the Mongrel Mob, in 'Pale Flower' it was the Filthy Few, who are usually associated with motorbikes and in 'Dark Horse' it is the Black Power, as indicated by the dark blue scarf. This blue scarf is a mark of distinction that would allow the narrator's friend, Nathan, to become a man according to his father and peers. The narrator and his two friends, Nathan and Te Araroa, pass the time of day by smoking marijuana, drinking whiskey and generally talking casually with each other. However, when the subject of girls and sex came up, Nathan mentions the disappearance of a particular woman that he believes "narked" on his father for whatever reason. On questioning Nathan more about what happened to this girl, Nathan tells the narrator he believes that his father and his associates probably killed her and disposed of the body before going to the police with information. There were consequences that may have placed his own life in jeopardy:

Nathan's dad would have got rid of her ages ago. He wouldn't have wanted to risk getting caught. But people had disappeared before in the past, and as far as I knew, mouths were shut tighter than a nun's cunt ... If I told someone, what would happen to me? Nathan knew that I knew. Maybe I'd disappear too (p. 161). It is just after this point that the narrator drives into town and is pulled over by the local police officer and taken to the station. The thought of the missing woman keeps cropping up in his mind and he has a crisis of conscious. After much deliberation, the narrator finally decides to tell the constable but is somewhat taken aback when the constable urges the narrator to keep the information to himself. 
For the narrator to even make that decision caused a huge dilemma and took a lot of courage. The narrator knew the risk involved with telling the authorities and so did the constable. The constable's action raises an issue of how small Māori communities deal with local problems that involve the law. Without speaking as an authority, it may be assumed that gangs in small remote communities often have their own unspoken set of rules. Critiquing the literature that features such conducts as "unspoken rules" can also be problematic for Māori critics because the issues are often situations that have not been documented and officially cannot be accounted for, other than mere speculation. Dealing with delicate and controversial topics in Māori literature is a challenge for the Māori critic; to certain situations or behaviour that would be socially criticised by mainstream. There have been other pieces of works in contemporary short fiction that feature similar occurrences such as rape, drugs and murder but after the backlash that affected Māori after the release of the films Once Were Warriors and What Becomes of the Broken Hearted, ${ }^{130}$ publications and features pertaining to those subjects have subdued. Whether it is because a reduced amount of people in mainstream society read short fiction than watch films, or Tawhai's narratives are relatively too new, or whether it is because the reading public are use to reading stories about abuse in Māori communities, Tawhai's fiction has not received as much criticism from the perspective of social realism from non-Māori critics.

One particular story published in Tawhai's collection, Luminous, came at a time when Māori ethics were being scrutinised. In Tawhai's story 'Butterflies and Moths' was released when Māori people were receiving a lot of criticism around the issue of child abuse. In 2007 a series of child abuse cases, each child being of Māori descent and

${ }^{130}$ What Becomes of the Broken Hearted, Dir. Ian Mune, New Zealand Film Commission, 1999. 
having Māori parents or guardians, were widely publicised in the media throughout Aotearoa. On 30 July 2007, a morning show called Breakfast, hosted by Paul Henry interviewed a guest named Christine Rankin. Rankin who works for the New Zealand Family Commission, discussed the issue of child abuse with Henry on national television. However, what they discussed was an issue that went beyond the initial problems of child abuse, it became an issue of Māori abusers. The discussion became intense to the point that the host Henry felt he had the right to ask Rankin's opinion and views with questions like: 'Is it reasonable to point the finger at Māori and say 'you are child abusers'?' (1); 'What's wrong with Māori?' (2); and 'Do we have to neuter these people ... don't we have to stop these people from having and caring for children?' Rankin concurred and supported Henry's accusations. ${ }^{131}$ The fact that such careless statements were made by Henry and Rankin who agreed that the possibility of Māori women being neutered was something that should be considered placed Māori at a distance. It insinuated that Māori people were not part of the national population but a helpless culture that needed monitoring by non-Māori. This prompts Māori to ask how our behaviour will or has been inspected and to whose standards. Just as Māori had to deal with the indictments surrounding domestic abuse after the release of such media as Once Were Warriors, then Māori people also risk a form of stereotyping from public reaction when fiction is published about issues that relate to contemporary events.

Glory, the protagonist in 'Butterflies and Moths', remembers how hard it can be for a mother raising children after finding the bones of an infant buried at the site of her excavation. Throughout the story she often compares small hardships to those

131 'TVNZ Ltd and Seymour - 2007-101' in a complaint to Broadcasting Standards Authority: Te Mana Whanonga Kaipāho [online] URL: http://www.bsa.govt.nz/decisions/2007/2007-101.htm accessed 25 May 2009. 
experienced as a young mother trying to raise five children, 'This isn't hot, she told herself. Being hot is being stuck in the suburbs all summer with five kids and no car' ( $\mathrm{p}$. 53). For Glory, her achievement of raising five children was more of a duty due to being born a woman. There was never any mention of other adults or her husband helping when she was in need of assistance and one can assume that Charlie took a very stereotypical masculine role in the household. For Glory, Charlie was there as a provider for his family and she was the primary caregiver. Charlie's lack of support for Glory to pursue her dreams is flattened and commented that her desire to attend a few university classes was a 'Waste of time' (p. 52). Charlie's dependence on Glory is seen when he is left at home and sometimes in the dark because he forgot to pay the power bill or is eating cold baked beans because he forgot to do the shopping. Glory no longer feels responsible for his dayto-day needs after her children have grown up and left home, Charlie now has to fend for himself in the house. She even changes her name in an attempt to reinvent herself in perhaps an effort to live the life she always wanted as a paleontologist.

When Glory and Charlie were parents to young children, their life was full and often difficult. With the pressure for Charlie to work, a crying baby in the middle of the night took its toll, 'Shut that bloody baby up ... I need some sleep! I've got work in the morning!' (p. 55). In Aotearoa the average age for woman's first marriage from 1966 to 1976 was 20-24 years old, which is young in comparison to women marrying in the millennium with the average age being in a woman's late 20 s to early $30 \mathrm{~s} .{ }^{132}$ Statistics New Zealand states that 'Māori women are less likely than non-Māori women to be partnered. The difference is largely due to the greater proportions who have never

\footnotetext{
132 'Woman are marrying later' in Statistics New Zealand: Tatauranga Aotearoa [online] URL: http://www.stats.govt.nz/analytical-reports/women-in-nz/women-are-marrying-later.htm accessed 26 May 2009
} 
married, rather than high rates of separation or divorce. ${ }^{133}$ Although there is never any mention of Glory and Charlie being married, it is assumed from the narrative that Glory and Charlie stayed together in a relationship when Glory became pregnant. 'Girls were girls, and then they were wives and mothers' (p. 52). A lot of women who had or have children young, struggled to cope and for Glory it was the repetitive duty of caring for the children as well having Charlie's dinner on the table. These expectations were common for young mothers in the 1960s through to the 80 s when equal opportunities for women were still becoming established.

Throughout 'Butterflies and Moths' the narrative keeps returning to Glory's past, discussing her experience as a mother but it is not until the last paragraph the narrator reveals the calm and curious woman Glory is, although not always like that. Glory resorts to shaking her first-born, Marama, late one night. It is not uncommon to have babies constantly waking throughout the night and for a mother who has to wake up every time the baby cries, it can become very exhausting.

But Marama was awake, and crying and screaming. It was the fifth time since Glory had gone to bed, and it had been going on night after night. 'Shut that bloody baby up!' Charlie had shouted ... And Glory had picked Marama up and shaken her hard, just to try and make her stop. But she had only cried louder. And Glory quite clearly remembered how there, in the dimness, she had wished her own baby dead.

This sort of behaviour is not exclusive to Māori mothers but to possibly all new mothers in general. There is always a chance that sleep deprivation may occur with new parents.

133 'Woman are marrying later' (2009) 
As far as the reader can tell, Glory's daughter, Marama, grew up fine. Marama is studying at a university in Australia and from the text message she sent to Glory on her birthday, maintains a healthy relationship with her mother.

In hindsight the action of shaking the baby was dangerous and an extreme of desperation but it is also this kind of literature that may be seen to reinforce streotypes of Māori child abuse. As previously mentioned, this story was released in 2007, when the media was featuring the child abuse cases of the Kahui twins and Nia Glassie. A report by the Childs Rights Information Network claimed:

The case of a three-year-old girl who was allegedly hung from a washing line and spun in a tumble-dryer has reignited debate in New Zealand about the touchy subject of child abuse within Māori communities ... It is the latest in a long series of shocking cases. A 22-year-old Auckland man, Chris Kahui, will stand trial later this year for the murder last June of his three-month-old twin sons, Chris and Cru. The 1994 film Once Were Warriors helped to bring the issue of violence within Māori families to the fore ... Although fictional, it focused attention on a taboo subject. Police statistics suggest Māori children are twice as likely as their white counterparts to be abused. Some agencies put the figure five times higher... Most experts attribute violence against children to poverty, unemployment, welfare dependence, alcoholism and alienation. Māori people are worse off than white New Zealanders on just about every social indicator. $^{134}$

If Māori critics read 'Butterflies and Moths' it would be important to consider the accounts of how the public is reacting to the Māori child abuse there would be enough

\footnotetext{
134 'NEW ZEALAND: Child abuse claims raise queries about Maori culture' in Childs Rights Information Network (2007) [online] URL: http://www.crin.org/violence/search/closeup.asp?infoID=14227 accessed 25 May 2009
} 
media to implicate unjust stereotyping. Contemporary literature is more than the narrative and what makes the piece contemporary, it is often a demonstration of influences and current events.

Publications and criticism surrounding issues involving Māori confrontations with the law or incidents that are morally questionable are still prevalent in contemporary Māori short fiction. For a lot of Māori writers including Alice Tawhai, addressing and writing about subjects such as identity, community, prejudices, and Indigenous injustices is shared with other Indigenous short fiction writers. In Aotearoa there has been a ebb and flow of stories since the 1980s that express how Māori people have adjusted to living within a bicultural nation (Māori and non-Māori). There have been stories that were produced for other Māori readers, stories expressing experiences not uncommon to other Māori. Although these topics aren't as common any longer, Tawhai does write about issues of Māori identity. Similar stories of Indigenous assertion are seen in Native American writing that features 'boarding school' experiences in books such as Mending Skins by Eric Gansworth and Australian Aboriginal writers who told the story of their 'stolen generation' like Nugi Garimara's, Follow the Rabbit-proof Fence.

It is also important to recognise that stories such as 'Butterflies and Moths' isn't just about one mother's act of desperation and exhaustion, it is also a story about a personal journey through motherhood, a woman's emotional and physical growth and her connection to the land. The discovery of the bones in the ground signifies a life cycle. The story of the life cycle is recounted in reverse with Glory beginning the story as a woman who is theoretically near an age of menopause. Menopause is commonly known as the 'change-of-life' and for Glory it is a time when she has decided to pursue what she 
has always been interested in, palaeontology. Comparisons are made between herself and her daughter about the opportunities and obligations expected of a woman when they were both roughly the same age. Unlike Glory, Marama is travelling overseas, acquiring an education

Tawhai's stories are contemporary, by evidence of dating her age and experience in places that existed at a particular time. There is nothing overt that makes any of her stories distinctly Māori; instead there is a series of smaller key points. Tawhai can be classified as a third-generation-writer. In American Indian Literary Nationalism, Weaver notes

Several years ago, at a panel organized on Craig Womack's and my work at the American Literature Association, Womack was asked what he saw as the future of Native American literature. His reply was simply, "More and funkier." As we now move toward the third generation of Native writers since the beginning of the Renaissance, I would certainly agree, as themes of loss ebb but themes of place and community remain vital and strong. ${ }^{135}$

In relation to this statement, Tawhai has started to move away from the sorts of stories that identify Māori existence as a form of struggle in a bicultural nation. Technically Tawhai's narrative may not differ much from other short fiction published in Aotearoa, but her content offers a distinct perspective separate to mainstream examples. Tawhai offers insight into contemporary Māori society through her fiction cast alongside a Māori society that is rooted in cultural values and belief systems. In her story 'Queen Bee' there are no obvious indications any characters are abiding by tikanga Māori but they are young Māori people growing up analogous to their community. What connects these

${ }^{135}$ Weaver, (2006) p. 74 
characters are their familiar backgrounds through education, social activities and friendships.

In her story 'Queen Bee' ${ }^{136}$ the narrator mentions that the character Darcy attended the Māori boys' boarding school St Stevens. In its time, St Stevens was an elite Māori boys' school that eventually closed down in 2000 because the ... economy was being totally restructured and primary and secondary industry laid off large numbers of workers. Māori families were severely affected and numbers ... families could no longer afford to pay boarding fees. At the same time Te Reo Māori started to be taught at increasing numbers of state schools and parents no longer had to send their sons and daughters to Māori boarding schools to learn Te Reo Māori and Tikanga Māori. ${ }^{137}$

Māori associated with Māori boarding schools often gave them an air of distinction because the school fees were expensive. This made one's eligibility to go schools like St Stevens exclusive to those who could afford to attend.

Any distinction of elitism is distinguished through Darcy's sexual antics within the social group he and Tanea associate with. Typical attitudes surrounding those Māori that attended boarding school often came with expectations of financial wealth and prosperity. Darcy appears to be aware of those expectations and often got pleasure out of showing off his trophies either through his sporting endeavours or his relationship with Tanea. His girlfriend Tanea has her reputation, although hers wasn't built through education and sporting achievements, her's attained through her beauty. The narrator,

\footnotetext{
${ }^{136}$ Alice Tawhai, 'Queen Bee' in Luminous (Wellington: Huia, 2007) pp. 28-33

${ }^{137}$ St Stevens and Queen Victoria Schools Trust, 'Closure of Stephen's School and Queen Victoria School' [online] URL: http://www.ssqv.org.nz/schools_closures.php accessed 11 May 2009
} 
Tanea's younger sister, praises her, 'Tanea always got what she wanted, and even I didn't mind, because she so obviously deserved it' (p. 28). There are mixed loyalties for the narrator. She has sex with Darcy without Tanea knowing so whether Tanea "deserves it" is questionable. The reader can question her integrity as a woman who is aware her partner is cheating on her; since Tanea and her friends are adamant that infidelity is wrong or that Tanea is also unfaithful to Darcy. Tanea was for the most part, the Queen Bee of this story and what is interesting to note is that for these characters is that society's perception of them is important.

In the American Indian Literary Nationalism Jace Weaver discusses two different prongs of American Indian literary nationalism with the first relating to 'the consideration of Native American literary output as separate and distinct from other national literatures' (p. 15). If these distinctions are considered to be separate from national literatures, then how would distinctions be notable from international literatures, more specifically Indigenous literatures. In terms of personal identity and the identity of Tawhai's works as Māori literature, the critic must consider the challenges and parameters of what it is to be Indigenous. Weaver questions American Indian literary nationalism and later goes on to explain that for him 'American Indian literary nationalism is processual.' ${ }^{138}$ Māori literary nationalism is the same not because this suggested practice is still in the developing stages but because the parameters of Māori literature and the reflections of its context are contentious. This is where I believe that the questioning of whether Māori literary nationalism can actually be likened to the practice of American Indian literary nationalism has its arguments for and against.

${ }^{138}$ Weaver, (2006) p. 38 
Māori and American Indians are both Indigenous/First Nations people that have been colonised by European countries and this can be observed through our literature. Weaver, Womack and Warrior reinforce the idea that American Indian literary nationalism is a distinct practice where no other culture can be included, yet, Māori literary nationalism share enough traits and can identify with them at an Indigenous level. In saying that, Māori literary nationalism could critique works such as Tawhai's and note that there are many insignificant idioms; therefore, Māori literary nationalism can only be applicable to Māori readers. 


\section{Conclusion}

Throughout this thesis I have looked at some of Tawhai's short fiction to try and determine how an approach like Māori literary nationalism would benefit her work in order to give a more productive critical analysis of the text. Ideally Māori literary nationalism would gather particular concepts and ideas under one framework to assist in making distinctions and highlighting aspects that make her work unique to Māori literature. Three major factors signify how an approach like Māori literary nationalism is a progressive shift towards better understanding of contemporary Māori literature for Māori critics, and inevitably, for Māori readers. The first of these factors will be an evaluation of how effective the model of American Indian literary nationalism is for Native literary criticism in the United States and why this particular model of critical theory has been chosen as a practice for Māori criticism to follow. I will then summarise where contemporary Māori literature is placed within contemporary literary discourse and argue for Māori literature to be given the opportunity to be read and critiqued on its own merits. Finally, I will look at what makes Tawhai's work so interesting and use her work as an example and an argument for the practice of Māori literary nationalism.

\section{American Indian Literary Nationalism}

In the appendix of American Indian Literary Nationalism, Simon Ortiz speaks of the ability with which Native Americans have over the years learnt to 'gather in many forms of the social-political colonizing force ... and make these forms meaningful in their own 
terms. ${ }^{139}$ For this particular research, it is important to note how American Indians have gathered and discussed their literature, the processes of developing a Native voice and the knowledge they have and can learn from each other, away from and colonial thought.

Ortiz goes on to say through an allegory of Indian celebrations that there are combinations of beliefs that include both Catholicism and American Indian spirituality. He notes that there is a 'celebration of the human spirit and the Indian struggle for liberation. ${ }^{140}$ It is liberating because American Indians, much like most Indigenous cultures have managed to take on certain aspects of a colonial force, like literature, and make it into something that is no longer a Western concept, but instead an American Indian creation.

Like American Indians, Māori people were on the verge of losing their language after British colonisation; period after there were various interactions with the French and Americans during the 1800 s when whaling was sought out as a means of trade on the coasts of Aotearoa. There were even some thoughts that Māori people would at some stage become extinct through integration with settlers or by death. For the American Indians, the full impact of their colonisation 'began with the arrival of the Spaniard priest, militarist, and fortune and slave seeker ${ }^{141}$ in the fifteenth century. Over the centuries much of their oral traditions have been transformed into the written word and although it may be argued that American Indians were forced to resign to a linguistic system that was not their own, it does not mean that they have forgotten their own identity. Indigenous people of both America and Aotearoa living today are evidence that

\footnotetext{
${ }^{139}$ Simon J. Ortiz, 'Appendix' in American Indian Literary Nationalism (Albuquerque, University of New Mexico: 2005) p. 254

${ }^{140}$ Simon J. Ortiz, 'Appendix' in American Indian Literary Nationalism (Albuquerque, University of New Mexico: 2005) p. 254

${ }^{141}$ Simon J. Ortiz, 'Appendix' in American Indian Literary Nationalism (Albuquerque, University of New Mexico: 2005) p. 256
} 
they still continue their lives and are able to do it through 'newer languages. ${ }^{142}$ Ortiz emphasises that:

There is not a question of authenticity here; rather, it is the way that Indian people have creatively responded to forced colonization. And this response has been one of resistance; there is not a clearer word for it than resistance ...

And it is this literature, based upon continuing resistance, which has given a particularly nationalistic character to the Native American. ${ }^{143}$

The idea of resistance that Ortiz mentions is an affirmation of how Indigenous people have developed through using new languages and literature to show, in effect, the residual adaptation of Indigenous people to preserve and persevere with our own values and perceptions of what it is to be Indigenous. By acknowledging our own Indigenous/Māori writers and their works, we as Indigenous/Māori readers are enforcing and supporting a growing literary movement that is defining a more acute perception and understanding our ethos. For further reading in the interest of American Indian literary nationalism, I recommend Craig S. Womack's Red on Red: Native American Literary Separatism (1999). The University of Minnesota Press exclaims that:

That is Craig Womack's argument in Red on Red. Indian communities have their own intellectual and cultural traditions that are well equipped to analyze Native literary production. These traditions should be the eyes through which the texts are viewed. To analyze a Native text with the methods currently dominant in the academy, according to the author, is like studying the stars with a magnifying glass ... Womack argues that the meaning of works by Native peoples inevitably changes through evaluation by the dominant culture. Red on Red is a call for self-

${ }^{142}$ Ortiz, (2005) p. 257
${ }^{143}$ Ortiz, (2005) p. 257 
determination on the part of Native writers and a demonstration of an important new approach to studying Native works - one that engages not only the literature, but also the community from which the work grew. ${ }^{144}$

Womack also features in my second recommendation which is a book called Reasoning Together: The Native Critics Collective made up of contributing writers. This is what University of Oklahoma Press had to say about the book:

Reasoning Together proposes nothing less than a paradigm shift in American Indian literary criticism, closing the gap between theory and activism by situating Native literature in real-life experiences and tribal histories. It is an accessible collection that will suit a wide range of courses — and will educate and energize anyone engaged in criticism of Native literature. ${ }^{145}$

\section{Māori Literary Nationalism}

Literature naturally evolves as social and literary dynamics change. To administer a literary practice to contemporary literature there must be literary criticisms and approaches in place to help analyse and explore the text appropriately. The term Māori literary nationalism maybe a new term, but the concepts behind this proposed approach are most definitely not new. As a literary theory, Māori literary nationalism would be drawing on different ideas and ways of looking at Māori literature in order to make particular distinctions that highlight what makes Māori literature different and unique. It is too early to say what affect Māori literary nationalism would have since it first has to be put into practice. Distinguishing what makes Māori literature unique and different is perhaps more pertinent to Māori readers. Throughout this thesis I have explored the short

\footnotetext{
144 'Book review' of Craig S. Womack, Red on Red: Native American Literary Separatism [online] URL: http://www.upress.umn.edu/Books/w/womack_red.html accessed 4 October 2009

145 'Book review' of Reasoning Together: The Native Critics Collective ( 2009)
} 
fiction of Alice Tawhai, not only to examine why her fiction has made an impact as a contemporary collection of works, but to try and find a way of reading her fiction that meets my needs as a Māori reader. Tawhai has produced works that meet and challenge the literary standards currently being produced in Aotearoa. Her work takes on subject matter that is relevant to the Indigenous culture of Aotearoa using technical devices such as themes and language that challenge mainstream literature. She gives an interpretation of contemporary Māori culture and provides material that concurs with social and artistic developments. It would be too easy to compare Tawhai's work with other contemporary short fiction in Aotearoa, written by non-Māori writers, in order to see a point of difference. In doing that all the reader would be doing is noticing what the fiction is saying about a non-Pākehā society. To see unique distinctions in regards to social and cultural realisms one would have to compare Tawhai's work to other Māori writers and artists or at least to other Indigenous writing such as Pacific, Australian Aboriginal, Canadian Aboriginal or American Indian writing.

Tawhai is just one writer of an increasing number of contemporary Māori writers emerging in Aotearoa. Her works reflected a time when Māori activism was rife in the late 1970 s through to the 1990 s, yet the stories were published later at a time when various Māori political movements have seen a push towards recognition of Māori sovereignty. The political and social mood of the nation undoubtedly has an influence on the reader, more so, if the reader belongs to the Māori nation. When the reader is able to identify a story as nothing more than a story rather than looking at the stories with a preconceived idea of the writer's background, in this case Tawhai life, they are able to form a faster relationship with the narrative. This particular way of looking at literature, primarily attributed to poetry, is called practical criticism. Practical criticism is just one 
demonstration of a concept gathered from other frameworks, helping to develop Māori literary nationalism. The main concept of an approach such as Māori literary nationalism would be the insider's view, which Māori readers would likely already be practising unconsciously when reading Māori text. Placing themselves as the "we" or "our" alongside the writer, not necessarily the text. As demonstrated in earlier chapters, contemporary text no longer focuses on the idea that Māori people are the central focus of a story.

Divergent as the text is, so too are the Māori of Aotearoa. The cultural "markers" that stereotyped us do not categorise Māori as Māori. Māori literary nationalism does not exclude any person who believes they can whakapapa back to an iwi of Aotearoa because all life experiences are important in giving voice and perspective when reading Māori narratives. A similar concept to Māori literary nationalism has also been discussed in other academic research as an approach that is "Kaupapa Māori”. In literature the idea behind a Māori-focused approach has potential as Māori scholar Alice Te Punga Somerville states:

Within the wonderful world of Māori scholarship, 'Kaupapa Māori’ ... has become a recognisable and oft-cited concept that attempts to grample with, and perhaps underwrite, the consideration of Māori-appropriate/Māori-centric/Māoribased research methodologies.' 146

Yet as shown in the Introduction of this thesis, Leonie Pihama explores the concept of Kaupapa Māori and demonstrates how this concept is one of those examples where there is no direct or appropriate translation in English. However, an understanding and

\footnotetext{
${ }^{146}$ Alice Te Punga Somerville, Nau Te Rourou, Nau te Rakau: The Oceanic, Indigenous, Postcolonial and New Zealand Comparative Contexts of Māori Writing in English (Cornell University, NY: United States of America, 2006) p. 6
} 
example for this literature is shown by American Indian literary nationalism, so until further developments, the umbrella name shall remain as Māori literary nationalism even if it does share ideals or values demonstrated in a kaupapa Māori concept. I reiterate once again, that Māori literary nationalism would be a safe space for Māori to share knowledge and ideas we can relate to Māori text, whether it is perceived through reflection, representations, creativity or imagination.

This literary approach offers another way of reading, a way that has drawn on the techniques and methods from other existing literary frameworks. Under the umbrella of one title, Māori literary nationalism is able to potentially apply aspects of postcolonialism, post-modernism, feminism, cultural studies, and many more contemporary frameworks that are commonly used today within the field of literature. I believe that one of the most important points about Māori literary nationalism is that it heavily suggests that for an approach like this to thrive, Māori critics and scholars must talk and keep abreast with current research and together find a way to move on. Generating scholarly techniques that assist in empowering Māori through this discipline can only be a positive thing towards asserting Māori sovereignty. For further reading relating to Māori literary nationalism I recommend Haere mai me tuhituhi he pukapuka; muri iho ka whawhai ai tātou: Reading te Rangikāheke by Arini May Lodger. ${ }^{147}$ This thesis will give readers another perspective on how an approach like American Indian literary criticism can be applied to Māori literature.

\footnotetext{
${ }^{147}$ Arini May Lodger, Haere mai me tuhituhi he pukapuka; muri iho ka whawhai ai tâtou: Reading te Rangikāheke (unpublished master's thesis, University of Victoria , 2008)
} 


\section{Alice Tawhai}

I never set out to propose a new literary approach when I first started reading Alice Tawhai's short stories. Tawhai's stories had been my starting point, but it was through my interest in her writing that I discovered I needed another way of reading her stories. Tawhai's work includes a variation of themes that I believe make more of an impact with contemporary readers because of the time period they have allegedly been written about. She often touches on subjects that have not been discussed or portrayed by a Māori writer, often giving the reader a snapshot of a life of someone living in Aotearoa

I have mentioned throughout this research that Tawhai is one of a number of contemporary Māori short fiction writers, but unlike Tawhai, many only publish one of two stories published in the Huia short stories series through the Pikihuia Awards for Māori Writers which are held every two years. I recommend that for further reading of contemporary short fiction by Māori writers one should consider Huia Short Stories $6^{148}$, $7,{ }^{149}$ and $8 .{ }^{150}$ Other short fiction Māori writers to think about reading are Paula Morris, Patricia Grace, Witi Ihimaera and Ngahuia Te Awekotuku. In an interview with Lynn Freeman for Radio New Zealand, Tawhai talked about another collection of short fiction in the process of being developed, and even considered idea of possibility of writing a novel one day, but we will have to wait and see.

\footnotetext{
${ }^{148}$ Huia Short Stories 6: Contemporary Māori Fiction (Wellington: Huia Publishers, 2005)

${ }^{149}$ Huia Short Stories 7: Contemporary Māori Fiction (Wellington: Huia Publishers, 2007)

${ }^{150}$ Huia Short Stories 8: Contemporary Māori Fiction (Wellington: Huia Publishers, 2009)
} 
Bibliography

\section{Primary Sources}

- About Māori: Profile' cited on FOMA: Federation of Māori Authorities, Me Uru Kahikatea [online] URL: http://www.foma.co.nz/about_maori/profile.htm accessed 3 May 2009

Alfred. Taiaiake Gerald, Peace, Power, Righteousness: An Indigenous Manifesto (Don Mills, ON: Oxford University Press, 1999)

- 'Book Review' American Indian Quarterly 29 (2005) p. 290

- 'Book review' of Craig S. Womack, Red on Red: Native American Literary Separatism [online] URL: http://www.upress.umn.edu/Books/w/womack_red.html accessed 4 October 2009

Bargh. Robyn, 'Huia Publishers' in an oral presentation to the Whitireia Community Polytechnic Diploma in Publishing course (Whitireia Community Polytechnic: Wellington, 2005)

Begay, Shawna, presenting a plenary session about Institute of American Indian Arts New Media Arts Program at the Native American Literary Symposium, Albuquerque, NM. 27 February 2009

Brooks, Lisa. 'At the Gathering Place' in American Indian Literary Nationalism (Albuquerque, University of New Mexico: 2005)

Butcher, M. (2003, August). What is Maori? Who is Pakeha? North \& South, pp. 36-47.

Courtney. Caroline, 'Maori in the middle', North and South (June 2008) 267: pp. 36-46

Chowdhury. Dave, 'Laws: Wanganui upset over 'h' decision', The Dominion Post, 17 September 2009

Clendinnen. Inga, 'The History Question: Who Owns the Past' in Quarterly Essay 23 (2006)

Ellis. Juniper, 'The Singing Word: Witi Ihimaera interviewed by Juniper Ellis', Journal of Commonwealth Literature 34.1, 1999, 176

Hill. David, 'Book Review: Small Holes in the Silence' in New Zealand Listener September 30-October 62006 Vol. 205 No 3464

Hill. Ruth, 'Maori rites cost taxpayers more', The Dominion Post, Tuesday, 13 January 2009

Hokowhitu. Brendan \& Jay Scherer, 'The Māori All Blacks and the Decentering of the White Subject: Hyperrace, Sport and the Cultural Logic of Late Capitalism' in Sociology of Sport Journal (2008) 25, pp. 243-262 
Holland. Charlie, 'Will Māori Literary Nationalism work in Aotearoa' (oral presentation) at the NativeAmerican Literary Symposium, Albuquerque, NM. 28 February 2009

- 'Huia Publishers: Voicing the voices and aspirations of Aotearoa' [online] URL: http://www.nzlive.com/en/huia-publishers accessed 10 March 2009

Hviding. Edvard, 'Between knowledges: Pacific studies and academic disciplines' in Contemporary Pacific (2003) 15:1

Ihimaera. Witi, Where's Waari?: A History of Māori through Short Story (Auckland: Reed Publishers, 2000) p. 10

Jackson. Anna, 'Around the World,' The Listener October 18-24 2008 Vol. 215 No 3571

Jamieson. Philippa 'Private Life' in New Zealand Listener, June 28-July 4 2008, Vol. 214: No 3555

Lawn. Jenny, 'Life under Neoliberalism in Contemporary Maori Literature' (oral presentation) at Auckland University, Aotearoa, 8 April 2009.

Lewis. Gregg L., 'Enrollment Procedures and Recourse' University of Oklahoma [online] URL: http://thorpe.ou.edu/OILS/enroll.html accessed 30 September 2009

Lodger. Arini May, Haere mai me tuhituhi he pukapuka; muri iho ka whawhai ai tātou: Reading te Rangikāheke (unpublished master's thesis, University of Victoria, 2008)

Lucashenko. Melissa, 'Muwi muwi-nyhin, binung goonj: boastful talk and broken ears' $W Q$ : Write Queensland July (2009)

Marsh. Selina Tusitala, 'The Land has Eyes: Pear ta ma 'on maf' Contemporary Pacific (2007) 19:1.

Marks. Kathy, 'Child abuse claims raise queries about Maori culture' in The Independent London: Jul 31, 2007.

Matthews. Philip, 'The X factor', The Press [Christchurch, New Zealand] 15 November 2008, D.1

Miscevic. Nenad, 'Nationalism', The Stanford Encyclopedia of Philosophy (Fall 2008 Edition), Edward N. Zalta (ed.), URL:

http://plato.stanford.edu/archives/fall2008/entries/nationalism/ accessed 14 May 2009

Moorfield, J. Te aka: Mäori-English, English-Mäori dictionary and index (Auckland: Pearson, 2005)

Mune. Dir. Ian, What Becomes of the Broken Hearted, New Zealand Film Commission, 1999

McRae. Jane, 'Patricia Grace - Interviewed by Jane McRae' in Judith Dell Panny, 'A

Cultural-Historical Reading of Patricia Grace's Cousins' Kōtare 6 (2006)

- 'NEW ZEALAND: Child abuse claims raise queries about Maori culture' in Childs Rights Information Network (2007) [online] URL:

http://www.crin.org/violence/search/closeup.asp?infoID=14227 accessed 25 May 2009 
- 'Once Were Warriors watched before death', The Dominion Post, Wednesday, 12 November 2008

Ortiz. Simon J., 'Forward: Speaking-Writing Indigenous Literary Sovereignty' in American Indian Literary Nationalism (Albuquerque, University of New Mexico: 2005)

Orr. Sarah, 'Girls in the Hood' on 60 Minutes: TV3, April 272009

Penguin unearthed, 'Review - The History Question: Who Owns the Past' [online] URL: http://penguinunearthed.wordpress.com/2006/12/31/review-the-history-question-whoowns-the-past/ accessed on 15 Jan 2008

Pettersen. Morten Kjeldseth, 'Once Were Warriors: The Aftermath' in Pacific Affairs 81:3

Pihama. Leonie, Fiona Cram, Sheila Walker. Creating methodological space: A literature review of Kaupapa Maori research Canadian Journal of Native Education. Edmonton: 2002. Vol. 26, Iss. 1

PM, 'Baxter, James, K', New Zealand Book Council [online] URL: http://www.bookcouncil.org.nz/writers/baxterjk.html accessed 1 May 2009

Price. Chris, 'Te Writing is on the air (w)here the wall once was', New Zealand Book Council [online] URL: http://www.bookcouncil.org.nz/writers/Going_West_keynote.pdf , accessed on 15 Jan 2008

Romaine. Suzanne, 'Contested Visions of History in Aotearoa New Zealand Literature: Witi Ihimaera's The Matriarch, The Contemporary Pacific, Volume 16, Number 1, Spring 2004

Rowe. Neil, 'Notes Towards a McCahon ABC' [online] URL: http://www.art-newzealand.com/Issues 1to40/mccahon08nr.htm accessed 14 May 2009

Skyler, 'A Reject Review', Reading the Maps URL: http://readingthemaps.blogspot.com/2008/04/reject-review.html accessed on 4 Jan 2009

Small, Vernon, 'Key calls Maori job summit', The Dominion Post, Saturday, 24 January 2009

Sommer. Doris, 'Resistant Texts and Incompetent Readers' in Poetics Today 15:4 (1994)

- 'Sturm. J C,' New Zealand Book Council [online] URL: http://www.bookcouncil.org.nz/writers/sturmjc.html accessed 2 Oct 2009

Tawhai. Alice, Festival of Miracles (Wellington: Huia Publishers Ltd, 2005)

Tawhai. Alice, Luminous (Wellington: Huia Publishers Ltd, 2007)

Tawake. Sandra, 'Transforming the insider-outsider perspective: Postcolonial fiction from the Pacific' in Contemporary Pacific, (2000) 12:1

Te Ahu, 'The Evolution of Contemporary Māori Protest', Maorinews.com [online] URL: http://maorinews.com/writings/papers/other/protest.html accessed 14 April 2009

Te Ao Hou: The New World, [online] URL:

http://teaohou.natlib.govt.nz/journals/teaohou/index.html accessed 19 September 2009. 
Te Ahukaramū Charles Royal, 'Can we Sustain Māori Literary Nationalism', public address at the Māori Writers National Hui, Wellington Town Hall, 19 October 2008

Te Punga Somerville. Alice, Nau Te Rourou, Nau te Rakau: The Oceanic, Indigenous Postcolonial and New Zealand Comparative Contexts of Māori Writing in English (Cornell University, NY: United States of America, 2006)

Te Punga Somerville. Alice, 'The Lingering War Captain: Māori Texts, Indigenous Contexts in Journal of New Zealand Literature, ed. Alex Calder (Waikato: University of Waikato, 2007)

Te Runga o Ngati Awa Nga Karoretanga o Mataatua Whare. The Wandering of the Carved House, Mataatua. Ngati Awa Research (1990)

Ten Canoes, Dir. Rolf de Heer, Palace Films, June 2006

The Best New Zealand Fiction: Volume 3, ed. Fiona Kidman (Auckland: Vintage, 2006)

The dictionary of New Zealand English: a dictionary of New Zealandisms on historical principles, ed. H.W. Orsman (Auckland: Oxford University Press, 1997)

The Reed dictionary of New Zealand English: the first dictionary of New Zealand English and New Zealand pronunciation, general editor, H.W. Orsman; revising editor, third edition, Nelson Wattie (Auckland: Reed, 2001)

Thiong'o. Ngugi wa, Decolonising the Mind: The Politics of Language in African Literature (London: James Currey Ltd., 1981)

Tuhiwai Smith. Linda, Decolonizing Methodologies: Research and Indigenous Peoples (Dunedin: Zed Books, 1999)

Vercoe. Andrew Eruera, Educating Jake: pathways to empowerment (Auckland: Harper Collins, 1998)

Ward. Vincent, Dir. The Rain of Children, New Zealand Film Commission: Te Tumu Whakaata Taonga. (2008)

Wareham Leonard, Louise, 'Festival of Miracles by Alice Tawhai', Leaf Salon URL: http://www.leafsalon.co.nz/archives/000670festival of miracles by alice tawhai.html accessed on 4 Jan 2009

Warrior. Robert, 'Native Critics in the World' in American Indian Literary Nationalism (Albuquerque, University of New Mexico: 2005)

Watkins. Tracy, 'UN Man 'stunned' to find Maori in cities', The Dominion Post, 6 April 2006

Weaver. Jace, American Indian Literary Nationalism (Albuquerque, University of New Mexico: 2005)

Welham. Keri, 'Family faces up to its shame', The Dominion Post, Thursday, 20 November 2008 
Womack. Craig S., Red on Red: Native American Literary Separatism (Oklahoma: University of Oklahoma Press, 1999)

Womack, Craig S., 'The Integrity of American Indian Claims' in American Indian Literary Nationalism (Albuquerque, University of New Mexico: 2005)

- 'Woman are marrying later' in Statistics New Zealand: Tatauranga Aotearoa [online] URL: http://www.stats.govt.nz/analytical-reports/women-in-nz/women-are-marrying-later.htm accessed 26 May 2009 


\section{Secondary Sources}

Battista. Jon, "Nga Ahorangi." Hecate 23.1 (1997): 143-145. Research

Library, ProQuest. Web. 4 Sep. 2009

Battista. Jon, "Te Pukapuka Kahui Korero.” Hecate 23.2 (1997): 160-191. Research Library, ProQuest. Web. 4 Sep. 2009.

Dunsford. Cathie, "Manawa Toa: Heart Warrior." Hecate 23.2 (1997): 67-75. Research Library, ProQuest. Web. 4 Sep. 2009.

Huia Short Stories 6: Contemporary Māori Fiction (Wellington: Huia Publishers, 2005)

Huia Short Stories 7: Contemporary Māori Fiction (Wellington: Huia Publishers, 2007)

Huia Short Stories 8: Contemporary Māori Fiction (Wellington: Huia Publishers, 2009)

Te Tū a Te Toka: He Ireretanga nō ngā Tai e Whāa, eds. Piripi Walker and Huriana Raven (Porirua: Tōtika Publications Ltd, 2006)

Walker. Ranginui, Ka whawhai tonu mātou: Struggle without end (Auckland: Penguin, 2004)

Whetu moana: Contemporary Polynesian poetry in English eds. by Albert Wendt, Reina Whaitiri and Robert Sullivan. (Auckland: Auckland University Press, 2003) 